\title{
Development and Evaluation of a Triplex TaqMan Assay and Next-Generation Sequence Analysis for Improved Detection of Xylella in Plant Material
}

\author{
Peter Bonants, ${ }^{\dagger}$ Yvonne Griekspoor, Ilse Houwers, Marjon Krijger, Patricia van der Zouwen, Theo A. J. van der Lee, \\ and Jan van der Wolf \\ Wageningen University and Research, Business Unit Biointeractions and Plant Health, 6700 AA Wageningen, The Netherlands
}

\begin{abstract}
Xylella fastidiosa is a heterogenous gram-negative bacterial plant pathogen with a wide host range covering over 300 plant species. Since 2013, in Europe, the presence of the pathogen is increasing in a part of the Mediterranean area, but it causes in particular severe disease problems in olive orchards in the Southern part of Italy. Various subspecies of the pathogen were also diagnosed in natural outbreaks and intercepted ornamental plants in Europe, among them Olea europaea, Coffea arabica, and Nerium oleander. The host range of the pathogen can vary, depending on the subspecies and even the strain. The availability of fast and reliable diagnostic tools is indispensable in management strategies to control diseases caused by $X$. fastidiosa. To improve the reliability of the TaqMan assay, currently widely used in surveys, a triplex TaqMan assay was developed in which two specific and sensitive TaqMan assays, previously designed for $X$. fastidiosa, were combined with an internal control. The triplex assay exhibited

the same diagnostic sensitivity as the simplex assays. In addition, the usefulness of a metagenomic approach using next-generation sequencing (NGS) was demonstrated, in which total DNA extracted from plant material was sequenced. DNA extracts from plant material free of $X$. fastidiosa, from artificially inoculated hosts plants or from naturally infected plants sampled in France, Spain, and Italy, or intercepted in Austria and the Netherlands, were analyzed for the presence of $X$. fastidiosa using the metagenomic approach. In all samples, even in samples with a low infection level, but not in the pathogen-free samples, DNA reads were detected specific for $X$. fastidiosa. In most cases, the pathogen could be identified to the subspecies level, and for one sample even the whole genome could be assembled and the sequence type could be determined. All results of NGS-analyzed samples were confirmed with the triplex TaqMan polymerase chain reaction and loop-mediated isothermal amplification.
\end{abstract}

Xylella fastidiosa is a gram-negative plant-pathogenic bacterium (Wells et al. 1987) widely distributed in the North, Central, and South Americas, where it causes different diseases in important crops, often resulting in high economic losses. The bacterium is present in the xylem of host plants, and it is transmitted by xylem sap-feeding insects from infected to uninfected areas. The host range for $X$. fastidiosa is broad, but symptoms are not always visible. Therefore, the risk of spread and introduction of $X$. fastidiosa into new areas is high (Almeida and Nunney 2015). Until recently, X. fastidiosa was only present in some countries across the Americas. In Europe the situation severely changed during the last few years. For the first time an outbreak in nature in the European Union was on olive trees (Olea europaea) in southern Italy (Apulia region) in 2013 (Saponari et al. 2013). Later X. fastidiosa was also found in Corsica, France, on Polygala myrtifolia and in the southeast Mediterranean coast of France on different hosts (EPPO 2015). After these introductions, X. fastidiosa has been found on oleander (Nerium oleander) in Germany (EPPO 2016a), on cherry and grapevine in Mallorca, Spain (EPPO 2016b), and last on the main continent of Spain in Andalusia on almond trees (EPPO 2017).

$X$. fastidiosa is a heterogeneous species and has been classified into four recognized subspecies (fastidiosa, multiplex, pauca, and san$d y i$ ), with a broad, largely nonoverlapping host range (Nunney et al. 2014a, c). Recently, another subspecies has been proposed, namely $X$. fastidiosa subsp. morus (Nunney et al. 2014b). It was suggested that this subspecies was the result of intersubspecific homologous recombination (Nunney et al. 2014c). To study biodiversity among Xylella isolates, a multilocus sequence typing (MLST) approach was

${ }^{\dagger}$ Corresponding author: Peter Bonants; E-mail: peter.bonants@wur.nl

Funding: This work was financed by the Topsector Horticulture and Starting Materials, the Ministry of Economic Affairs of The Netherlands and by VBN, Plantum, LTO Netherlands, Anthos, Program Fund Greenhouse and Naktuinbouw (KV1509-030).

Accepted for publication 7 September 2018.

C 2019 The American Phytopathological Society used by analyzing the sequence of seven housekeeping genes (leuA, petC, malF, cysG, holC, nuoL, and gltT) and developing an MLST scheme (Yuan et al. 2010). Based on this MLST approach, isolates can also be divided into sequence types (STs) that, partly, provide insight into the host specificity of X. fastidiosa (https://pubmlst.org/ xfastidiosa/). At the time of writing, more than 80 different STs have been found. The different STs are clustered into subspecies.

For the detection of the bacterium in symptomatic and asymptomatic plants, various detection methods have been developed based on different principles. The antibody-based ELISA kits from Agritest and Loewe have been validated for many host plants including olive, oleander, almond, citrus, oak, grape, and other species (e.g., weeds) (Loconsole et al. 2014). Already in 1994, a conventional polymerase chain reaction (PCR) for $X$. fastidiosa had been developed (Firrao and Bazzi 1994; Minsavage et al. 1994) based on the sequence data available at that time. Since then, various real-time PCR methods for the detection of the bacterium have been developed (Francis et al. 2006; Harper et al. 2010, erratum 2013; Li et al. 2013; Ouyang et al. 2013; Schaad et al. 2002). Reisenzein (2017) evaluated five different real-time PCR assays for diagnostic specificity and sensitivity and concluded that the TaqMan PCRs designed by Harper et al. and Ouyang et al. performed equally well. A loop-mediated isothermal amplification (LAMP) method was developed for $X$. fastidios $a$ detection in plant sap and in infected insects (Harper et al. 2010; Yaseen et al. 2015). Ito and Suzaki (2017) developed a multiplex qPCR method for simultaneous detection of phytoplasmas and Xylella spp., and in which an internal plant DNA positive control was integrated.

In all available nucleic acid-based amplification methods for the detection of $X$. fastidiosa a single locus has been used as a target sequence, making the assays prone to false-positive or false-negative results. Moreover, current assays lack a proper control for extraction efficiency of sample DNA, as well as for PCR inhibition. This can be overcome by addition of bacteria to each sample that are phylogenetically related to Xylella, to be used as a DNA extraction and amplification control (Kuske et al. 2006). This approach to improve the reliability of TaqMan assays was previously used for detection of major human pathogens (Janse et al. 2010).

The genetic information for the development of diagnostic methods is growing fast, owing to the reduction in sequencing costs and 
the availability of next-generation sequencing (NGS) technology. The first full genome sequence of $X$. fastidiosa was described in 2000 (Simpson et al. 2000), but in the meantime genomes of over $40 \mathrm{X}$. fastidiosa isolates have been assembled. The complete draft genome of the ST53 strain, which caused olive quick decline syndrome in Italy (Giampetruzzi et al. 2015a, 2017a; Loconsole et al. 2016), showed considerable genetic relatedness to the genomes of $X$. fastidiosa subsp. pauca isolates. Later on, Giampetruzzi et al. (2017b) analyzed 27 finished or draft genome sequences of $X$. fastidiosa available in the GenBank database. Using comparative genomics of isolates and $X$. fastidiosa-infected plant material, which came from Costa Rica and Honduras, it was concluded that the $X$. fastidiosa ST53 isolate from olive in Southern Italy may have originated from Central America (Loconsole et al. 2016).

The increasing information on genome sequences is not only useful in the design of $X$. fastidiosa-specific diagnostics but also in an unbiased metagenomic approach. The high throughput capacity of NGS allows sequencing of total sample DNA and potentially offers a means not only to detect the pathogen but also to characterize it to the subspecies and even strain level, without the need for pathogen cultivation. This can make the technique interesting for forensic studies, in particular in case of fastidious organisms such as X. fastidiosa.

So far, in plant health studies, metagenomics have mainly been used to investigate the presence of the microbiota in different habitats, including endophytic and rhizosphere communities (Mendes et al. 2011).

The objectives of the present study were, first, to develop a triplex TaqMan assay combining, in the same amplification reaction, two previously designed primer and probe sets for X. fastidiosa with a primer and probe set targeting a bacterial internal control. Second, the possibilities of NGS coupled with metagenomic analysis were explored using DNA extracted from X. fastidiosa-infected host plants to detect the bacterium on a subspecies level.

\section{Materials and Methods}

Bacterial strains. $X$. fastidiosa subsp. fastidiosa $\mathrm{LMG} 17159$ and $X$. fastidiosa subsp. multiplex LMG 9063 were collected at BCCM/ LMG (Gent, Belgium). X. fastidiosa subsp. pauca (CoDiRO) was obtained from M. Saponari (Bari, Italy). The bacterium Acidovorax cattleya (Acat) strain NBC 430 was obtained from Naktuinbouw (Roelofarendsveen, the Netherlands) and was used as an internal control in molecular testing. Bacteria were stored at $-80^{\circ} \mathrm{C}$.

DNA isolation from (un)infected plants and from pure bacterial colonies. Nicotiana tabacum plants (cultivar Petit Havana SR1) were grown from seeds to a four or 10 leaf stage before inoculation. Catharanthus roseus plants were grown from seeds to six and 12 leaf stage before inoculation. Plants were cultivated in the greenhouse in potting soil (Lentse potgrond) at temperatures of approximately 20 to $25^{\circ} \mathrm{C}$ and with a photoperiod of $16 \mathrm{~h}$ of light. Before inoculation the potting soil was left dry for one night to ensure the uptake of the liquid inoculum at the time of inoculation. For inoculum preparation, bacteria were grown on modified periwinkle wilt growth medium at $27^{\circ} \mathrm{C}$. Suspensions of the bacteria with a density of approximately $10^{8} \mathrm{CFU} / \mathrm{ml}$ were prepared in phosphate buffered saline (PBS; EPPO 2016b). The turbidity of these suspensions was comparable with a McFarland standard of 0.5 . The percentage of viable cells was determined using a LIVE/DEAD BacLight bacterial viability kit following the manufacturer's instructions (L7012, Thermo Fisher Scientific).

Host plants ( $N$. tabacum and C. roseus) were inoculated by placing $10 \mu l$ of the bacterial suspension in the axils of two leaves per plant. With a sterile needle the droplets were punctured five times in the direction of the main stem. After inoculation, plants were kept at a photoperiod of $16 \mathrm{~h}$ of light at $27^{\circ} \mathrm{C}$ and $8 \mathrm{~h}$ of dark at $21^{\circ} \mathrm{C}$ at $50 \%$ relative humidity. After 4 months, different parts of the plants were harvested and stored at $-20^{\circ} \mathrm{C}$ until DNA extraction. Plant parts were homogenized in universal heavy-duty Bioreba bags with an intermediate synthetic layer (400014, Bioreba AG, Switzerland), using a hammer. The volume of 0.01 M PBS buffer ( $\mathrm{pH} 7.2$ ) added after homogenization was based on the weight of the plant material (1 to 14 g) in a 1:10 ratio $(w / v)$. The homogenized material was agitated at room temperature for $30 \mathrm{~min}$. The extract was poured into a $50-\mathrm{ml}$ screw-cap tube (525-0156, VWR). After taking out $1.5 \mathrm{ml}$ for analysis and storage, the remaining fluid was centrifuged for $20 \mathrm{~min}$ at $10,000 \times g\left(4^{\circ} \mathrm{C}\right)$ to concentrate the bacteria. The pellet was resuspended in $1.5 \mathrm{ml}$ of $0.01 \mathrm{M}$ PBS (pH 7.2). The internal control bacterium Acat was grown in tryptic soy broth medium to a density of $\mathrm{OD}_{600}=0.8$. The cell suspension was diluted $100 \times$ with $0.01 \mathrm{M}$ PBS, and $5 \mu \mathrm{l}$ was added to the plant extract before DNA extraction, giving a cycle threshold $(\mathrm{Ct})$ value of approximately 30 for the Acat TaqMan PCR. DNA was isolated from $75 \mu \mathrm{l}$ of both the extracts before and after concentration supplemented with the $5 \mu$ l of Acat internal control using the QuickPick Plant DNA kit (Bio-Nobile) as recommended by the manufacturer. DNA from pure colonies was isolated using the Wizard Magnetic DNA Purification System for Food from Promega (catalogue no. FF3750). DNA extracts (24) from Xylella-free and Xylella-infected host plants were obtained from different countries (Italy, France, Spain, Austria, and the Netherlands). DNA samples were extracted according EPPO protocols PM7/024 (QuickPick SML Plant DNA Kit-based extraction [Bio-Nobile]).

TaqMan assays. Simplex TaqMan assays were performed according to the methods of Harper et al. (2010, erratum 2013) and Ouyang et al. (2013). The sequences of the primers and probes are provided in Table 1. The composition of the simplex reaction mixtures was as follows: 1× Premix Ex Taq (TaKaRa, RR390A), $300 \mathrm{nM}$ forward and reverse primer (XF-F and XF-R or Xf.csp6-F and Xf.csp6-R), $100 \mathrm{nM}$ probe (XF-P [FAM] or Xf.csp6-P [HEX]), and $2 \mu \mathrm{l}$ of isolated sample DNA. PCR-grade water was added to a final volume of $20 \mu \mathrm{l}$. The reaction conditions were as follows: $2 \mathrm{~min}$ at $95^{\circ} \mathrm{C}$ followed by 40 cycles of $15 \mathrm{~s}$ at $95^{\circ} \mathrm{C}$ and $40 \mathrm{~s}$ at

Table 1. List of primers and probes and their sequences for TaqMan polymerase chain reaction and loop-mediated isothermal amplification

\begin{tabular}{|c|c|c|c|}
\hline Primer name & Sequence $\left(5^{\prime}-3^{\prime}\right)$ & 5' Dye & Reference \\
\hline $\mathrm{XF}-\mathrm{F}$ & CACGGCTGGTAACGGAAGA & & Harper et al. (2010); erratum 2013 \\
\hline XF-R & GGGTTGCGTGGTGAAATCAAG & & Harper et al. (2010); erratum 2013 \\
\hline XF-P & TCGCATCCCGTGGCTCAGTCC & FAM & Harper et al. (2010); erratum 2013 \\
\hline Xf.csp6-F & CCCATTACGCTTCAACCATT & & Ouyang et al. (2013) \\
\hline Xf.csp6-R & CCCAATCCATACGACTTGCT & & Ouyang et al. (2013) \\
\hline Xf.csp6-P & GGTGTGATTCGCAGCAAGGGC & HEX & Ouyang et al. (2013) \\
\hline Acat 2-F & TGTAGCGATCCTTCACAAG & & This publication \\
\hline Acat 2-R & TGTCGATAGATGCTCACAAT & & This publication \\
\hline Acat 2-P & CTTGCTCTGCTTCTCTATCACG & TXR & This publication \\
\hline XF-F3 & CCGTTGGAAAACAGATGGGA & & Harper et al. (2010) \\
\hline XF-B3 & GAGACTGGCAAGCGTTTGA & & Harper et al. (2010) \\
\hline XF-FIP & ACCCCGACGAGTATTACTGGGTTTTTCGCTACCGAGAACCACAC & & Harper et al. (2010) \\
\hline XF-BIP & GCGCTGCGTGGCACATAGATTTTTGCAACCTTTCCTGGCATCAA & & Harper et al. (2010) \\
\hline XF-LoopF & TGCAAGTACACACCCTTGAAG & & Harper et al. (2010) \\
\hline XF-LoopB & TTCCGTACCACAGATCGCT & & Harper et al. (2010) \\
\hline
\end{tabular}


Table 2. Sequences of the gBlocks used in this study ${ }^{\mathrm{a}}$

\begin{tabular}{|c|c|}
\hline gBlock name & Sequence $\left(5^{\prime}-3^{\prime}\right)$ \\
\hline gBlock Xylella &  \\
\hline gBlock IC & 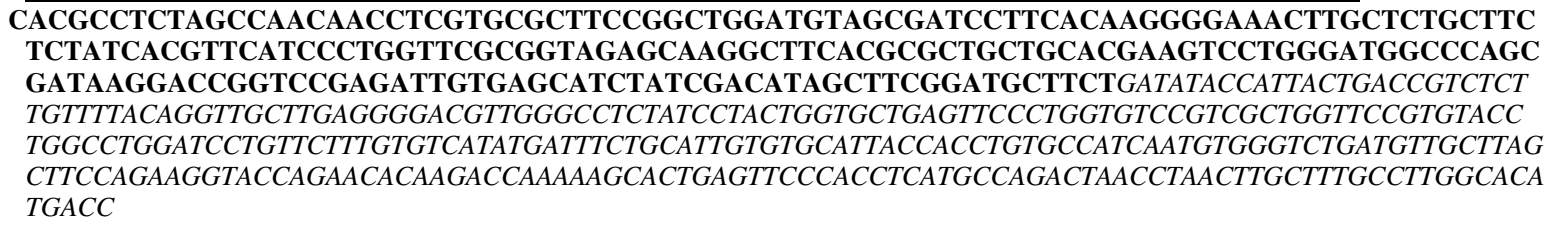 \\
\hline
\end{tabular}

a gBlock Xylella: bold = Harper amplicon; italic = universal TaqMan control (UTC) amplicon; and underline = Ouyang amplicon. $\mathrm{gBlock}$ internal control (IC): bold = Acidovorax cattleyae amplicon; and italic = UTC amplicon.

Table 3. Genome sequences of 40 Xylella fastidiosa reference genomes deposited in the NCBI database and used in this study ${ }^{\mathrm{a}}$

\begin{tabular}{|c|c|c|c|c|c|c|c|}
\hline $\begin{array}{l}\text { Xylella } \\
\text { subspecies }\end{array}$ & Strain & Host & Location & ST & $\begin{array}{c}\text { NCBI } \\
\text { accession }\end{array}$ & $\begin{array}{l}\text { Size } \\
(\mathbf{M b})\end{array}$ & Scaffolds \\
\hline fastidiosa & DSM 10026 & Vitis vinifera & U.S.A., Florida & 2 & IMG-taxon 2595698223 & 2.43165 & 63 \\
\hline fastidiosa & ATCC 35879 & Vitis vinifera & U.S.A., Florida & 2 & NZ_JQAP00000000.1 & 2.52233 & 16 \\
\hline fastidiosa & CFBP8073 & Coffea arabica & France (import Mexico) & 75 & LKESO0000000 & 2.58215 & 328 \\
\hline fastidiosa & EB92.1 & Sambucus nigra & U.S.A. & 1 & NZ_AFDJ00000000.1 & 2.47543 & 168 \\
\hline fastidiosa & GB514 & Vitis vinifera & U.S.A., Texas & 1 & NC_017562.1 & 2.51738 & 2 \\
\hline fastidiosa & M23 & Prunus dulcis & U.S.A., California & 1 & NC_010577.1 & 2.57399 & 2 \\
\hline fastidiosa & Stag's Leap & Grapevine & U.S.A., California, Napa Valley & 1 & LSMJ01000001 to 15 & 2.5108 & 15 \\
\hline fastidiosa & Temecula1 & Vitis vinifera & U.S.A., California, Temecula & 1 & NC_004556.1 & 2.52115 & 2 \\
\hline fastidiosa/sandyi & $\mathrm{CO} 33$ & Coffea & Italy (import Costa Rica) & 72 & NZ_LJZW00000000.1 & 2.68193 & 96 \\
\hline morus & MUL0034 & Morus alba & U.S.A., Maryland & 30 & NZ_CP006740.1 & 2.66658 & 2 \\
\hline morus & Mul-MD & Morus alba & U.S.A. & 29 & NZ_AXDP00000000.1 & 2.52055 & 101 \\
\hline multiplex & BB01 & Vaccinium corymbosum & U.S.A., Georgia & 42 & GCA_001886315 & 2.51152 & 83 \\
\hline multiplex & CFBP8416 & Polygala myrtifolia & France, Corsica & 7 & ASM197147v1 & 2.46675 & 128 \\
\hline multiplex & CFBP8417 & Spartium junceum & France, Corsica & 6 & ASM197150v1 & 2.50498 & 256 \\
\hline multiplex & CFBP8418 & Spartium junceum & France, Corsica & 6 & ASM197146v1 & 2.51397 & 271 \\
\hline multiplex & $\begin{array}{c}\text { ATCC } 35871 \\
\text { (PLS0135) }\end{array}$ & Plum salicina & U.S.A., Georgia & 41 & AUAJ01000001 to 62 & 2.41626 & 58 \\
\hline multiplex & Dixon & Prunus dulcis & U.S.A. & 6 & NZ AAAL02000001 to 32 & 2.62233 & 32 \\
\hline multiplex & Griffin-1 & Quercus ruba & U.S.A. & 7 & NZ_AVGA00000000.1 & 2.38731 & 84 \\
\hline multiplex & M12 & Prunus dulcis & U.S.A., California & 7 & NC_010513.1 & 2.47513 & 1 \\
\hline multiplex & Sycamore Sy-VA & Platanus occidentalis & U.S.A., Virginia & 8 & NZ_JMHP00000000.1 & 2.47588 & 128 \\
\hline pauca & 32 & Coffea sp. & Brazil & 16 & NZ_AWYH00000000.1 & 2.60755 & 56 \\
\hline pauca & 3124 & Coffea sp. & Brazil & 16 & GCA__001456195.1 & 2.74859 & 1 \\
\hline раиса & 11399 & Orange tree & Brazil & 11 & ASM168441v1 & 2.73606 & 36 \\
\hline pauca & De Donno & Olea europaea & Italy, Apulia & 53 & ASM211787v1 & 2.54374 & 2 \\
\hline pauca & $\mathrm{Fb} 7$ & Citrus & Argentina, Corrientes & 69 & ASM145633v2 & 2.77337 & 2 \\
\hline pauca & Hib4 & Hibiscus & Brazil, Jarinu, Sao Paulo & 70 & ASM145631v1 & 2.87755 & 2 \\
\hline pauca & $\mathrm{J} 1 \mathrm{a} 12$ & Citrus & Brazil, Jales, Sao Paulo & 11 & ASM145623v1 & 2.86724 & 3 \\
\hline pauca & $\operatorname{Pr} 8 \mathrm{x}$ & Plum & Brazil, Jarinu, Sao Paulo & 14 & ASM145629v1 & 2.70582 & 2 \\
\hline раиса & U24D & Citrus sinensis & Brazil, Ubarana, Sao Paulo & 13 & ASM145627v1 & 2.73249 & 2 \\
\hline pauca & $6 c$ & Coffea sp. & Brazil & 14 & NZ_AXBS01000046.1 & 2.60398 & 19 \\
\hline pauca & $9 \mathrm{a} 5 \mathrm{c}$ & Citrus sinensis & Brazil, Sao Paula & 13 & NC_002488.3 & 2.73175 & 3 \\
\hline раиса & CFBP8072 & Coffea arabica & France (import Ecuador) & 74 & LKDK01000001 to 278 & 2.49666 & 278 \\
\hline pauca & CoDiRO & Olea europaea & Italy & 53 & JUJW01000001 to 12 & 2.54293 & 12 \\
\hline pauca & COF0324 (33) & Coffea & $\begin{array}{l}\text { Brazil, Minas Gerais State, } \\
\text { Varginha }\end{array}$ & 14 & LRVG01000001 to 143 & 2.77256 & 143 \\
\hline pauca & COF0407 (C18) & Coffea & $\begin{array}{l}\text { Costa Rica, San Jose Province, } \\
\text { Curridabat }\end{array}$ & 53 & LRVJ01000001 to 172 & 2.53847 & 172 \\
\hline pauca & CVC0251 (BB6) & Citrus sinensis & $\begin{array}{l}\text { Brazil, Sao Paulo State, } \\
\text { Bebedouro }\end{array}$ & 1 & LRVE01000001 to 130 & 2.74025 & 130 \\
\hline pauca & CVC0256 (Col-11) & Citrus sinensis & Brazil, Sao Paulo State, Colima & 1 & LRVF01000001 to 128 & 2.70214 & 128 \\
\hline pauca & OLS0478 (Narcisco 1) & Nerium oleander & $\begin{array}{l}\text { Costa Rica, San Jose Province, } \\
\text { Sabanilla }\end{array}$ & 53 & LRVI0100001 to 48 & 2.55541 & 48 \\
\hline pauca & OLS0479 (Narcisco 3) & Nerium oleander & $\begin{array}{l}\text { Costa Rica, San Jose Province, } \\
\text { Sabanilla }\end{array}$ & 53 & LRVH01000001 to 183 & 2.53996 & 183 \\
\hline sandyi & Ann-1 & Nerium oleander & $\begin{array}{l}\text { U.S.A., California, Palm } \\
\text { Springs }\end{array}$ & 5 & NZ_CP006696.1 & 2.78091 & 2 \\
\hline
\end{tabular}

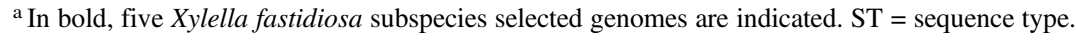


$60^{\circ} \mathrm{C}$ in the Bio-Rad CFX384 thermocycler. Duplex TaqMan assays were performed using the following reaction mixture: $1 \times$ Premix Ex Taq (TaKaRa, RR390A), $300 \mathrm{nM}$ forward primers XF-F or Xf.csp6$\mathrm{F}$ and Acat 2-F and $300 \mathrm{nM}$ reverse primers XF-R or Xf.csp6-R and Acat 2-R, $100 \mathrm{nM}$ probes XF-P (FAM) or Xf.csp6-P (HEX) and Acat $2-\mathrm{P}$ (Texas Red), and $2 \mu \mathrm{l}$ of isolated DNA, filled to a final volume of $20 \mu l$ with PCR-grade water. The reaction conditions were similar to those described for the simplex assays. The composition of the Triplex TaqMan PCR reaction mixture was as follows: $1 \times$ Premix
ExTaq (TaKaRa, RR390A), $300 \mathrm{nM}$ forward primers XF-F, Xf. csp6-F, and Acat 2-F, and $300 \mathrm{nM}$ reverse primers XF-R, Xf.csp6$\mathrm{R}$, and Acat 2-R, $100 \mathrm{nM}$ probes XF-P (FAM), Xf.csp6-P (HEX), and Acat 2-P (TR), and $2 \mu l$ of sample DNA. PCR-grade water was added to a final volume of $20 \mu \mathrm{l}$. Acat primer and probe sequences were provided by Naktuinbouw (Roelofarendsveen, the Netherlands) and designed based upon unique amplified fragment length polymorphisms for Acat. The reaction conditions were similar to those described for the simplex assays. Two gBlocks (sequences

A

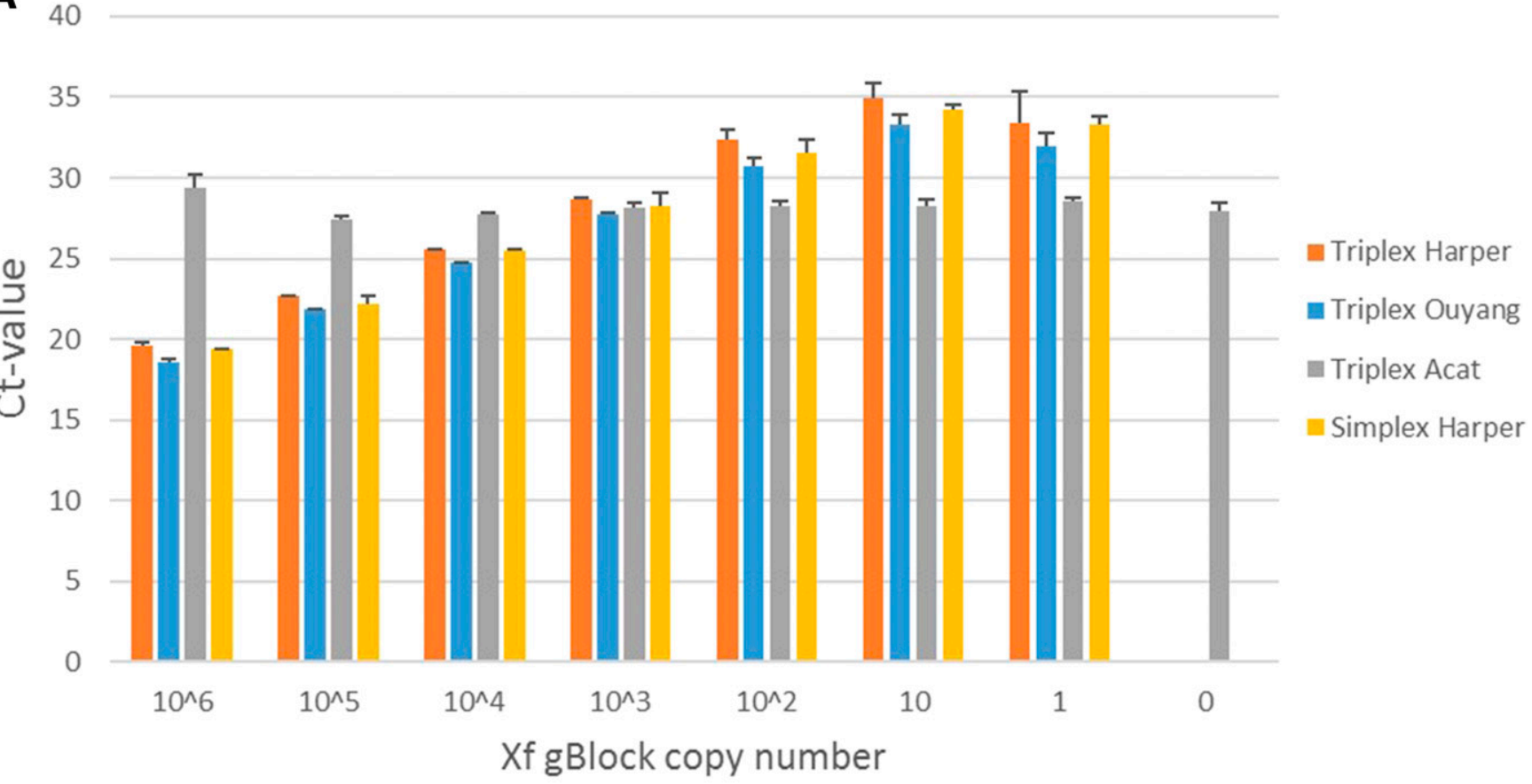

B

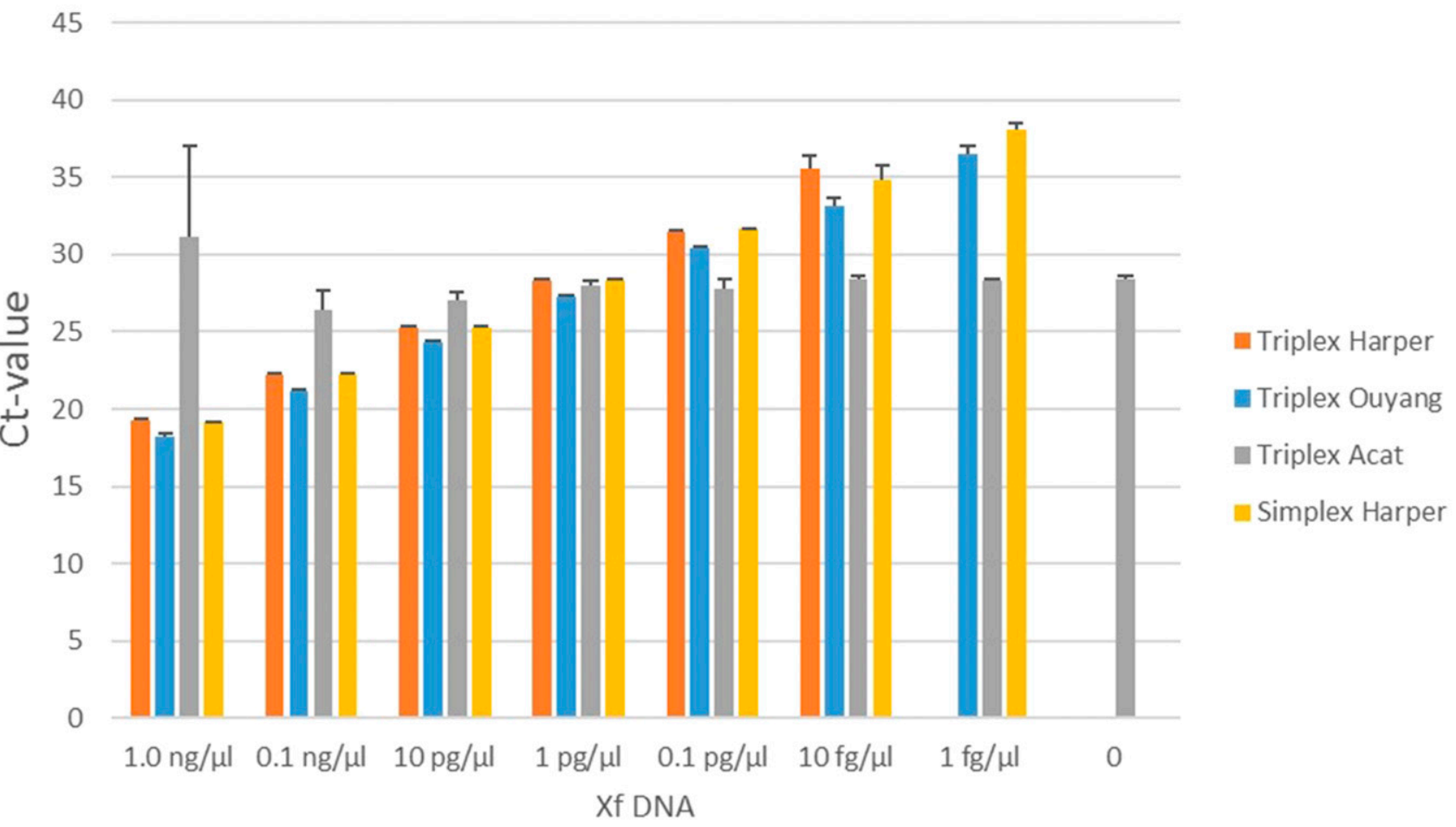

Fig. 1. A, Average Ct values (of four replicates) and standard deviation of a triplex TaqMan assay for $X y l e l l a$ fastidiosa (Xf) and a simplex TaqMan assay on a dilution series of $X f$ gBlocks combined with a standard concentration (100 copies) of the internal control gBlock based on sequences of Acidovorax cattleya (Acat). B, Average Ct values (of four replicates) and the standard deviation of a triplex TaqMan assay for Xf and a simplex TaqMan assay on a dilution series of DNA of Xf (isolate subsp. multiplex LMG 9063) combined with standard concentration $(10 \mathrm{pg} / \mu \mathrm{l})$ of DNA extracted from the internal control Acat. 
Table 4. Ct values of duplex and triplex TaqMan PCR Xylella fastidiosa $(X f)$ on DNA extracts from healthy tobacco plants and plants infected with $X f$ subsp. pauca (CoDiRO strain) in a background of DNA of the internal control Acidovorax cattleyae (Acat) DNA ${ }^{\mathrm{a}}$

\begin{tabular}{|c|c|c|c|c|c|c|}
\hline \multirow{2}{*}{$\begin{array}{l}\text { Healthy or } \\
\text { infected }\end{array}$} & \multirow{2}{*}{$\begin{array}{l}\text { Tobacco } \\
\text { plant no. }\end{array}$} & \multicolumn{2}{|c|}{ Duplex } & \multicolumn{3}{|c|}{ Triplex } \\
\hline & & Harper & $\overline{\text { Acat }}$ & Harper & Ouyang & $\overline{\text { Acat }}$ \\
\hline Healthy & 20 & $\ldots$ & 30.53 & $\ldots$ & $\ldots$ & 29.62 \\
\hline Healthy & 21 & $\ldots$ & 30.93 & $\ldots$ & $\ldots$ & 31.06 \\
\hline Healthy & 22 & $\ldots$ & 30.55 & $\ldots$ & $\ldots$ & 29.50 \\
\hline Healthy & 23 & $\ldots$ & 30.00 & $\ldots$ & $\ldots$ & 32.86 \\
\hline$X f$ infected & 34 & 30.91 & 30.05 & 30.69 & 30.48 & 29.66 \\
\hline$X f$ infected & 35 & 25.17 & 29.36 & 25.07 & 25.04 & 28.94 \\
\hline$X f$ infected & 46 & 28.85 & 29.19 & 28.88 & 28.98 & 28.79 \\
\hline$X f$ infected & 47 & 25.85 & 28.36 & 25.99 & 26.02 & 28.31 \\
\hline \multirow[t]{5}{*}{ Controls } & PBS Acat & $\ldots$ & 30.47 & $\ldots$ & $\ldots$ & 30.51 \\
\hline & PBS & $\ldots$ & $\ldots$ & $\ldots$ & $\ldots$ & $\ldots$ \\
\hline & $\mathrm{NC}$ & $\ldots$ & $\ldots$ & $\ldots$ & $\ldots$ & $\ldots$ \\
\hline & PC Acat & $\ldots$ & 19.39 & $\ldots$ & $\ldots$ & 19.98 \\
\hline & PC Xfm & 20.46 & $\ldots$ & 20.63 & 20.77 & $\ldots$ \\
\hline
\end{tabular}

a $\ldots=$ target sequences not detected; $\mathrm{NC}=$ negative control (water); $\mathrm{PC}$ Acat $=$ positive control DNA of Acat; PC Xfm = positive control DNA of $X f$ subsp. multiplex (isolate LMG 9063). provided in Table 2) were ordered at Integrated DNA Technologies: (i) gBlock Xylella, covering the amplicon sequence of the Harper and Ouyang TaqMan assays with a universal template control (UTC) sequence in between, and (ii) gBlock internal control, covering the amplicon sequence of the internal control (Acat) TaqMan PCR combined with a UTC sequence. A highly efficient TaqMan assay has been developed to target this UTC sequence as a control on the quality of the gBlock (unpublished). All primers and probes were also ordered from Integrated DNA Technologies. gBlocks were evaluated in simplex and triplex TaqMan PCR; DNA from infected tobacco plants and 24 DNA samples from different host plants were evaluated in duplex and triplex TaqMan PCR using the protocols described above. Samples were scored as positive when $\mathrm{Ct}$ values were $<40$ and the amplification curve was exponential.

LAMP. LAMP was performed according to the method of Harper et al. (2010). The composition of the reaction mix was as follows: $15 \mu$ l of ISO-001 (OptiGene, U.K.), $1.6 \mu \mathrm{M} \mathrm{XF-FIP} \mathrm{and} \mathrm{XF-BIP} \mathrm{pri-}$ mers, $0.2 \mu \mathrm{M}$ XF-F3 and XF-B3 primers, $0.8 \mu \mathrm{M}$ XF-LoopF and XF-LoopB primers, and $2 \mu l$ of isolated DNA or $5 \mu$ l of cell suspension. The sequences of the primers are provided in Table 1. PCRgrade water was added to a final volume of $25 \mu$. The reaction conditions were $30 \mathrm{~min}$ amplification at $65^{\circ} \mathrm{C}$ followed by a temperature gradient from 98 to $80^{\circ} \mathrm{C}\left(0.01^{\circ} \mathrm{C} / \mathrm{s}\right)$ to determine the melting curve

Table 5. Next-generation sequencing results of the 24 DNA samples from (un)infected plant material derived from the mapping on the five reference genomes (subspecies) of Xylella fastidiosa (Xf) using the random or ignore option (numbers listed as random/ignore) ${ }^{\mathrm{a}}$

\begin{tabular}{|c|c|c|c|c|c|c|c|c|c|c|c|c|}
\hline \multirow[b]{2}{*}{ No. } & \multirow[b]{2}{*}{ No. } & \multirow[b]{2}{*}{ Lab } & \multirow[b]{2}{*}{ Country } & \multirow[b]{2}{*}{ Sample } & \multirow{2}{*}{$\begin{array}{l}\text { Total number of } \\
\text { trimmed reads } \\
\text { (paired) }\end{array}$} & \multirow{2}{*}{$\begin{array}{c}\text { Total number } \\
\text { of } X f \text { mapped } \\
\text { reads }\end{array}$} & \multicolumn{5}{|c|}{$\begin{array}{c}\text { Number of reads mapped on reference } \\
\text { genomes of } X f \text { subspecies }\end{array}$} & \multirow{2}{*}{$\begin{array}{c}\text { Tentative } \\
\text { subspecies } \\
\text { identification }\end{array}$} \\
\hline & & & & & & & $\begin{array}{c}\text { fastidiosa } \\
\text { (Temecula1) }\end{array}$ & $\begin{array}{c}\text { pauca } \\
\text { (CoDiRO) }\end{array}$ & $\begin{array}{l}\text { multiplex } \\
\text { (M12) }\end{array}$ & $\begin{array}{l}\text { sandyi } \\
\text { (Ann-1) }\end{array}$ & $\begin{array}{c}\text { morus } \\
\text { (MUL0034) }\end{array}$ & \\
\hline 0 & 1 & WUR & NL & Clean tobacco sap & $6,682,324$ & $0 / 0$ & $0 / 0$ & $0 / 0$ & $0 / 0$ & $0 / 0$ & $0 / 0$ & No Xylella \\
\hline 4 & 2 & WUR & NL & $\begin{array}{l}10^{6} / \mathrm{ml} \mathrm{CoDiRO} \\
\text { in tobacco sap }\end{array}$ & $5,226,354$ & $974 / 926$ & $4 / 0$ & 958/924 & $4 / 2$ & $4 / 0$ & $4 / 0$ & раиса \\
\hline 5 & 3 & WUR & NL & $\begin{array}{l}10^{5} / \mathrm{ml} \mathrm{CoDiRO} \\
\text { in tobacco sap }\end{array}$ & $5,077,454$ & $64 / 62$ & $0 / 0$ & $64 / 62$ & $0 / 0$ & $0 / 0$ & $0 / 0$ & раиса \\
\hline 6 & 4 & WUR & NL & $\begin{array}{r}10^{4} / \mathrm{ml} \mathrm{CoDiRO} \\
\text { in tobacco sap }\end{array}$ & $5,243,020$ & $2 / 2$ & $0 / 0$ & $2 / 2$ & $0 / 0$ & $0 / 0$ & $0 / 0$ & pauca \\
\hline 8 & 5 & WUR & NL & $\begin{array}{r}\text { CoDiRO inf. } \\
\text { tobacco } 12\end{array}$ & $5,659,458$ & $15,828 / 14,548$ & $40 / 0$ & $15,638 / 14,548$ & $48 / 0$ & $52 / 0$ & $50 / 0$ & раиса \\
\hline 10 & 6 & WUR & NL & $\begin{array}{l}\text { CoDiRO inf. } \\
\text { Catharanthus } 34\end{array}$ & $5,928,822$ & $2,826 / 2,650$ & $6 / 0$ & $2,808 / 2,648$ & $8 / 2$ & $4 / 0$ & $0 / 0$ & pauca \\
\hline 13 & 7 & AGES & $\mathrm{AU}$ & $\begin{array}{l}\text { AGES471/15; } \\
\text { intercepted Coffea }\end{array}$ & $5,445,824$ & $368 / 226$ & $136 / 80$ & $14 / 12$ & $36 / 20$ & $96 / 64$ & $86 / 50$ & $\begin{array}{l}\text { Probably } \\
\text { fastidiosa }\end{array}$ \\
\hline 16 & 8 & NVWA & NL & $\begin{array}{l}\text { No. } 1 \text {; intercepted } \\
\text { Coffea }\end{array}$ & $5,398,218$ & $242 / 158$ & $94 / 70$ & $10 / 4$ & $26 / 10$ & $68 / 48$ & $44 / 26$ & $\begin{array}{l}\text { Probably } \\
\text { fastidiosa }\end{array}$ \\
\hline 17 & 9 & IPSP & I & Polygala myrtifolia & $5,788,412$ & $0 / 0$ & $0 / 0$ & $0 / 0$ & $0 / 0$ & $0 / 0$ & $0 / 0$ & No Xylella \\
\hline 18 & 10 & IPSP & I & Lavandula stoechas & $6,234,054$ & $0 / 0$ & $0 / 0$ & $0 / 0$ & $0 / 0$ & $0 / 0$ & $0 / 0$ & No Xylella \\
\hline 19 & 11 & IPSP & I & Nerium oleander & $6,132,890$ & $0 / 0$ & $0 / 0$ & $0 / 0$ & $0 / 0$ & $0 / 0$ & $0 / 0$ & No Xylella \\
\hline 20 & 12 & IPSP & I & Olea europaea & $6,035,114$ & $0 / 0$ & $0 / 0$ & $0 / 0$ & $0 / 0$ & $0 / 0$ & $0 / 0$ & No Xylella \\
\hline 21 & 13 & IPSP & I & $\begin{array}{l}\text { APL 3XM; inf. } \\
\text { Polygala myrtifolia }\end{array}$ & $5,391,348$ & $3,120 / 2,894$ & $2 / 0$ & $3,078 / 2,894$ & $12 / 0$ & $22 / 0$ & $6 / 0$ & pauca \\
\hline 23 & 14 & IPSP & I & $\begin{array}{l}\text { APL9M; inf. } \\
\text { Lavandula stoechas }\end{array}$ & $5,229,400$ & $2,568 / 2,362$ & $8 / 0$ & $2,524 / 2,360$ & $10 / 2$ & $18 / 0$ & $8 / 0$ & pauca \\
\hline 24 & 15 & IPSP & I & $\begin{array}{l}\text { APL4XM; inf. } \\
\text { Olea europaea }\end{array}$ & $7,054,528$ & $4,158 / 3,896$ & $12 / 0$ & $4,104 / 3,896$ & $14 / 0$ & $12 / 0$ & $16 / 0$ & pauca \\
\hline 25 & 16 & IPSP & I & $\begin{array}{l}\text { APL OL2-bis; inf. } \\
\text { Nerium oleander }\end{array}$ & $7,758,550$ & $396 / 370$ & $4 / 0$ & $390 / 370$ & $2 / 0$ & $0 / 0$ & $0 / 0$ & pauca \\
\hline 26 & 17 & CSIC & ES & $\begin{array}{l}\text { 5387; inf. Prunus } \\
\quad \text { dulcis }\end{array}$ & $5,152,978$ & $3,356 / 2,434$ & $2,860 / 2,388$ & $24 / 0$ & $60 / 26$ & $86 / 6$ & $326 / 14$ & fastidiosa \\
\hline 27 & 18 & CSIC & ES & $\begin{array}{l}\text { 5626; inf. Olea } \\
\text { europaea europaea }\end{array}$ & $5,944,912$ & $2,092 / 1,598$ & $62 / 16$ & $10 / 2$ & $1,720 / 1,476$ & $58 / 16$ & $242 / 88$ & multiplex \\
\hline 28 & 19 & CSIC & ES & $\begin{array}{l}\text { 5382; inf. Polygala } \\
\text { myrtifolia }\end{array}$ & $5,596,520$ & $1,824 / 1,414$ & $34 / 6$ & $18 / 2$ & $1,576 / 1,362$ & $32 / 6$ & $164 / 38$ & multiplex \\
\hline 29 & 20 & CSIC & ES & $\begin{array}{l}\text { 5402; inf. Olea } \\
\text { europaea europaea }\end{array}$ & $6,450,282$ & $130 / 104$ & $4 / 2$ & 94/88 & $8 / 2$ & $6 / 4$ & $18 / 8$ & раиса \\
\hline 30 & 21 & CSIC & ES & $\begin{array}{l}\text { EM_1; inf. Prunus } \\
\text { dulcis }\end{array}$ & $5,442,524$ & $6,172 / 4,724$ & $146 / 28$ & $34 / 6$ & $5,172 / 4,490$ & $114 / 20$ & $706 / 180$ & multiplex \\
\hline 32 & 22 & ANSES & $\mathrm{F}$ & $\begin{array}{l}\text { 326.1(A); inf. } \\
\text { Spartium junceum }\end{array}$ & $6,214,696$ & $351,534 / 274,880$ & $7,820 / 1,578$ & $1,644 / 270$ & $301,838 / 263,482$ & $7,096 / 1,880$ & $33,136 / 7,670$ & multiplex \\
\hline 33 & 23 & ANSES & $\mathrm{F}$ & $\begin{array}{l}327.2(\mathrm{~A}) ; \text { inf. } \\
\text { Coronilla glauca }\end{array}$ & $5,398,932$ & $66,652 / 50,828$ & $1,590 / 310$ & $710 / 72$ & $56,284 / 48,436$ & $1,428 / 388$ & $6,640 / 1,622$ & multiplex \\
\hline 34 & 24 & ANSES & $\mathrm{F}$ & $\begin{array}{l}328.2 \text { (A); inf. } \\
\text { Polygala myrtifolia }\end{array}$ & $5,443,864$ & $43,038 / 32,742$ & $1,158 / 208$ & $328 / 48$ & $36,540 / 31,430$ & $906 / 200$ & $4,106 / 856$ & multiplex \\
\hline
\end{tabular}

a Italic numbers = negative read mapping; and bold = positive read mapping using random or ignore settings. With the random setting, a read that mapped equally on more than one reference genome was randomly selected. With the ignore setting, a read that mapped equally on several reference genomes was ignored. Sample sources and countries: WUR = Wageningen UR, Wageningen, the Netherlands (NL); AGES = Austrian Agency for Health and Food Safety, Vienna, Austria (AU); NVWA = Dutch Food and Consumer Product Safety Authority, Wageningen, the Netherlands; IPSP = Institute for Sustainable Protection, Bari, Italy (I); CSIC = Spanish National Research Council, Coruna, Spain (ES); and ANSES = French Agency for Food, Environmental and Occupational Health \& Safety, Angers, France (F). 
Reactions were performed in a Genie II or Genie III device (OptiGene, U.K.).

NGS. In total, 24 DNA samples from $X$. fastidiosa-infected or $X$. fastidiosa-free plants were sequenced. The DNA samples were obtained from colleagues in different countries working with this bacterium. DNA was isolated from symptomatic and asymptomatic plant material according to EPPO protocols (EPPO 2016a). In most cases the ST was determined. In the workflow created for the analysis of these samples $40 \mathrm{X}$. fastidiosa genomes, which were available in the NCBI Genomes database (data download on October 8, 2017), were included. The metadata of these 40 genomes are listed in Table 3. The DNA samples were prepared for NGS by making random sheared shotgun libraries using the TruSeq Nano DNA Library Prep kit (single index) following the manufacturer's protocol (Illumina, San Diego, CA). With the HiSeq PE Rapid Cluster Kit V2 the samples were loaded on a paired-end flow cell. For sequencing, the HiSeq 2500 machine was used. The sequencing procedure was operated at the Business Unit Bioscience, Wageningen University \& Research (Wageningen, the Netherlands). After sequencing, 250-bp paired-end reads were generated. The data were analyzed using the CLC Genomics Workbench 11.01 and earlier versions (Qiagen, Aarhus, Denmark). Before the analysis was started, the sequences were trimmed (quality limit 0.05 ) to improve the read quality and remove the adapters. The trimmed reads (in pairs) were used in three different workflows. For the determination of the subspecies, a reference-based read mapping was performed using five reference genomes (Table 3, in bold) representing the five subspecies: $X$. fastidiosa subsp. fastidiosa (Temecula1), X. fastidiosa subsp. pauca (CoDiRO), X. fastidiosa subsp. multiplex (M12), X. fastidiosa subsp. sandyi (Ann-1), and $X$. fastidiosa subsp. morus (MUL0034). The read mapping was done twice: once with the map randomly option and once with the ignore option in the nonspecific match handling. The map randomly option means that, if a read can be equally mapped to the reference genome of more than one subspecies, it randomly selects one of those subspecies. When using the ignore option, those reads were not mapped at all and were ignored. For both workflows, a length fraction of 0.98 and a similarity fraction of 0.98 were set. When these high stringent settings were used in combination with the ignore option, reads that were mapped with a similar quality to different (strongly related) subspecies were excluded from the mapping. Only reads that were highly specific and mapped in pairs

Table 6. Results of a metagenomics analysis of 24 DNA samples from plant material infected with Xylella fastidiosa (Xf) or from Xylella-free plant material using genome sequences of $40 X f$ reference genomes deposited in the NCBI database. Indicated are the number of reads mapped (random/ignore function) of the 24 samples on the 40 reference genomes. ${ }^{\text {a }}$

\begin{tabular}{|c|c|c|c|c|c|c|c|c|c|c|c|c|c|c|c|}
\hline \multirow[b]{2}{*}{ Subsp. } & \multirow[b]{2}{*}{ Isolate no. } & \multirow[b]{2}{*}{ ST } & \multicolumn{13}{|c|}{ Sample no. } \\
\hline & & & 1 & 2 & 3 & 4 & 5 & 6 & 7 & 8 & 9 & 10 & 11 & 12 & 13 \\
\hline $\bar{p}$ & CoDiRO & 53 & $0 / 0$ & $170 / 0$ & $8 / 0$ & $0 / 0$ & $2,424 / 4$ & $478 / 2$ & $0 / 0$ & $0 / 0$ & $0 / 0$ & $0 / 0$ & $0 / 0$ & $0 / 0$ & $482 / 4$ \\
\hline$p$ & De Donno & 53 & $0 / 0$ & $160 / 0$ & $14 / 0$ & $0 / 0$ & $2,368 / 36$ & $428 / 2$ & $0 / 0$ & $2 / 0$ & $0 / 0$ & $0 / 0$ & $0 / 0$ & $0 / 0$ & $450 / 8$ \\
\hline$p$ & OLS0479 & 53 & $0 / 0$ & $156 / 0$ & $8 / 0$ & $0 / 0$ & $2,082 / 0$ & $382 / 0$ & $0 / 0$ & $2 / 0$ & $0 / 0$ & $0 / 0$ & $0 / 0$ & $0 / 0$ & $338 / 0$ \\
\hline$p$ & OLS0478 & 53 & $0 / 0$ & $126 / 0$ & $16 / 0$ & $0 / 0$ & $2,230 / 8$ & $378 / 0$ & $0 / 0$ & $0 / 0$ & $0 / 0$ & $0 / 0$ & $0 / 0$ & $0 / 0$ & $440 / 0$ \\
\hline$p$ & $\mathrm{COF} 0407$ & 53 & $0 / 0$ & $134 / 2$ & $10 / 0$ & $2 / 0$ & $2,114 / 4$ & $382 / 2$ & $0 / 0$ & $0 / 0$ & $0 / 0$ & $0 / 0$ & $0 / 0$ & $0 / 0$ & $440 / 0$ \\
\hline$p$ & $\mathrm{~J} 1 \mathrm{a} 12$ & 11 & $0 / 0$ & $10 / 0$ & $0 / 0$ & $0 / 0$ & $252 / 0$ & $72 / 0$ & $2 / 0$ & $2 / 0$ & $0 / 0$ & $0 / 0$ & $0 / 0$ & $0 / 0$ & $62 / 0$ \\
\hline$p$ & $\mathrm{CVC} 0256$ & 11 & $0 / 0$ & $18 / 0$ & $0 / 0$ & $0 / 0$ & $230 / 0$ & $36 / 0$ & $2 / 0$ & $0 / 0$ & $0 / 0$ & $0 / 0$ & $0 / 0$ & $0 / 0$ & $66 / 0$ \\
\hline$p$ & $\mathrm{CVC} 0251$ & 11 & $0 / 0$ & $12 / 0$ & $2 / 0$ & $0 / 0$ & $266 / 0$ & $30 / 0$ & $0 / 0$ & $0 / 0$ & $0 / 0$ & $0 / 0$ & $0 / 0$ & $0 / 0$ & $66 / 0$ \\
\hline$p$ & 11399 & 11 & $0 / 0$ & $18 / 0$ & $0 / 0$ & $0 / 0$ & $232 / 0$ & $42 / 0$ & $0 / 0$ & $2 / 0$ & $0 / 0$ & $0 / 0$ & $0 / 0$ & $0 / 0$ & $50 / 0$ \\
\hline$p$ & $9 \mathrm{a} 5 \mathrm{c}$ & 13 & $0 / 0$ & $10 / 0$ & $0 / 0$ & $0 / 0$ & $322 / 0$ & $48 / 0$ & $2 / 0$ & $0 / 0$ & $0 / 0$ & $0 / 0$ & $0 / 0$ & $0 / 0$ & $50 / 0$ \\
\hline$p$ & U24D & 13 & $0 / 0$ & $8 / 0$ & $2 / 0$ & $0 / 0$ & $270 / 0$ & $48 / 0$ & $0 / 0$ & $0 / 0$ & $0 / 0$ & $0 / 0$ & $0 / 0$ & $0 / 0$ & $40 / 0$ \\
\hline$p$ & $6 c$ & 14 & $0 / 0$ & $10 / 0$ & $0 / 0$ & $0 / 0$ & $284 / 0$ & $70 / 0$ & $0 / 0$ & $0 / 0$ & $0 / 0$ & $0 / 0$ & $0 / 0$ & $0 / 0$ & $72 / 0$ \\
\hline$p$ & $\operatorname{Pr} 8 x$ & 14 & $0 / 0$ & $22 / 0$ & $2 / 0$ & $0 / 0$ & $312 / 0$ & $50 / 0$ & $0 / 0$ & $2 / 0$ & $0 / 0$ & $0 / 0$ & $0 / 0$ & $0 / 0$ & $66 / 0$ \\
\hline$p$ & COF0324 & 14 & $0 / 0$ & $16 / 0$ & $2 / 0$ & $0 / 0$ & $304 / 0$ & $58 / 0$ & $0 / 0$ & $0 / 0$ & $0 / 0$ & $0 / 0$ & $0 / 0$ & $0 / 0$ & $64 / 0$ \\
\hline$p$ & 3124 & 16 & $0 / 0$ & $6 / 0$ & $0 / 0$ & $0 / 0$ & $266 / 0$ & $46 / 0$ & $0 / 0$ & $2 / 0$ & $0 / 0$ & $0 / 0$ & $0 / 0$ & $0 / 0$ & $60 / 0$ \\
\hline$p$ & 32 & 16 & $0 / 0$ & $16 / 0$ & $0 / 0$ & $0 / 0$ & $234 / 0$ & $42 / 0$ & $0 / 0$ & $0 / 0$ & $0 / 0$ & $0 / 0$ & $0 / 0$ & $0 / 0$ & $36 / 0$ \\
\hline$p$ & $\mathrm{Fb} 7$ & 69 & $0 / 0$ & $28 / 0$ & $0 / 0$ & $0 / 0$ & $276 / 0$ & $48 / 0$ & $0 / 0$ & $0 / 0$ & $0 / 0$ & $0 / 0$ & $0 / 0$ & $0 / 0$ & $52 / 0$ \\
\hline$p$ & Hib4 & 70 & $0 / 0$ & $14 / 0$ & $0 / 0$ & $0 / 0$ & $384 / 0$ & $52 / 0$ & $0 / 0$ & $0 / 0$ & $0 / 0$ & $0 / 0$ & $0 / 0$ & $0 / 0$ & $86 / 0$ \\
\hline$p$ & CFBP8072 & 74 & $0 / 0$ & $32 / 0$ & $0 / 0$ & $0 / 0$ & $794 / 0$ & $126 / 0$ & $10 / 4$ & $6 / 0$ & $0 / 0$ & $0 / 0$ & $0 / 0$ & $0 / 0$ & $166 / 0$ \\
\hline$m$ & Dixon & 6 & $0 / 0$ & $0 / 0$ & $0 / 0$ & $0 / 0$ & $6 / 0$ & $4 / 0$ & $6 / 0$ & $0 / 0$ & $0 / 0$ & $0 / 0$ & $0 / 0$ & $0 / 0$ & $0 / 0$ \\
\hline$m$ & CFBP8418 & 6 & $0 / 0$ & $2 / 0$ & $0 / 0$ & $0 / 0$ & $10 / 0$ & $2 / 0$ & $4 / 0$ & $2 / 0$ & $0 / 0$ & $0 / 0$ & $0 / 0$ & $0 / 0$ & $0 / 0$ \\
\hline$m$ & CFBP8417 & 6 & $0 / 0$ & $2 / 0$ & $0 / 0$ & $0 / 0$ & $4 / 0$ & $0 / 0$ & $0 / 0$ & $0 / 0$ & $0 / 0$ & $0 / 0$ & $0 / 0$ & $0 / 0$ & $2 / 0$ \\
\hline$m$ & CFBP8416 & 7 & $0 / 0$ & $0 / 0$ & $0 / 0$ & $0 / 0$ & $10 / 0$ & $2 / 0$ & $2 / 0$ & $0 / 0$ & $0 / 0$ & $0 / 0$ & $0 / 0$ & $0 / 0$ & $0 / 0$ \\
\hline$m$ & M12 & 7 & $0 / 0$ & $0 / 0$ & $0 / 0$ & $0 / 0$ & $6 / 0$ & $2 / 0$ & $0 / 0$ & $2 / 0$ & $0 / 0$ & $0 / 0$ & $0 / 0$ & $0 / 0$ & $4 / 0$ \\
\hline$m$ & Griffin-1 & 7 & $0 / 0$ & $2 / 0$ & $0 / 0$ & $0 / 0$ & $2 / 0$ & $0 / 0$ & $4 / 0$ & $0 / 0$ & $0 / 0$ & $0 / 0$ & $0 / 0$ & $0 / 0$ & $2 / 0$ \\
\hline$m$ & $\begin{array}{l}\text { Sycamore } \\
\text { Sy-VA }\end{array}$ & 8 & $0 / 0$ & $0 / 0$ & $0 / 0$ & $0 / 0$ & $12 / 0$ & $2 / 0$ & $4 / 0$ & $2 / 0$ & $0 / 0$ & $0 / 0$ & $0 / 0$ & $0 / 0$ & $0 / 0$ \\
\hline$m$ & ATCC35871 & 41 & $0 / 0$ & $0 / 0$ & $0 / 0$ & $0 / 0$ & $2 / 0$ & $0 / 0$ & $0 / 0$ & $0 / 0$ & $0 / 0$ & $0 / 0$ & $0 / 0$ & $0 / 0$ & $0 / 0$ \\
\hline$m$ & BB01 & 42 & $0 / 0$ & $0 / 0$ & $0 / 0$ & $0 / 0$ & $10 / 0$ & $0 / 0$ & $8 / 2$ & $2 / 0$ & $0 / 0$ & $0 / 0$ & $0 / 0$ & $0 / 0$ & $2 / 0$ \\
\hline$f$ & EB92.1 & 1 & $0 / 0$ & $0 / 0$ & $0 / 0$ & $0 / 0$ & $6 / 0$ & $0 / 0$ & $4 / 0$ & $0 / 0$ & $0 / 0$ & $0 / 0$ & $0 / 0$ & $0 / 0$ & $0 / 0$ \\
\hline$f$ & M23 & 1 & $0 / 0$ & $0 / 0$ & $0 / 0$ & $0 / 0$ & $6 / 0$ & $0 / 0$ & $16 / 0$ & $4 / 0$ & $0 / 0$ & $0 / 0$ & $0 / 0$ & $0 / 0$ & $2 / 0$ \\
\hline$f$ & GB514 & 1 & $0 / 0$ & $0 / 0$ & $0 / 0$ & $0 / 0$ & $6 / 0$ & $2 / 0$ & $2 / 0$ & $4 / 0$ & $0 / 0$ & $0 / 0$ & $0 / 0$ & $0 / 0$ & $4 / 0$ \\
\hline$f$ & Stag's Leap & 1 & $0 / 0$ & $4 / 0$ & $0 / 0$ & $0 / 0$ & $10 / 0$ & $0 / 0$ & $10 / 0$ & $6 / 0$ & $0 / 0$ & $0 / 0$ & $0 / 0$ & $0 / 0$ & $0 / 0$ \\
\hline$f$ & Temecula1 & 1 & $0 / 0$ & $0 / 0$ & $0 / 0$ & $0 / 0$ & $6 / 0$ & $0 / 0$ & $8 / 0$ & $0 / 0$ & $0 / 0$ & $0 / 0$ & $0 / 0$ & $0 / 0$ & $0 / 0$ \\
\hline$f$ & DSM 10026 & 2 & $0 / 0$ & $0 / 0$ & $0 / 0$ & $0 / 0$ & $8 / 0$ & $2 / 0$ & $10 / 0$ & $8 / 0$ & $0 / 0$ & $0 / 0$ & $0 / 0$ & $0 / 0$ & $2 / 0$ \\
\hline$f$ & ATCC35879 & 2 & $0 / 0$ & $0 / 0$ & $0 / 0$ & $0 / 0$ & $8 / 0$ & $0 / 0$ & $8 / 0$ & $4 / 0$ & $0 / 0$ & $0 / 0$ & $0 / 0$ & $0 / 0$ & $2 / 0$ \\
\hline$f$ & CFBP8073 & 75 & $0 / 0$ & $0 / 0$ & $0 / 0$ & $0 / 0$ & $10 / 0$ & $0 / 0$ & $28 / 2$ & $12 / 2$ & $0 / 0$ & $0 / 0$ & $0 / 0$ & $0 / 0$ & $0 / 0$ \\
\hline$f / s$ & $\mathrm{CO} 33$ & 72 & $0 / 0$ & $0 / 0$ & $0 / 0$ & $0 / 0$ & $36 / 0$ & $0 / 0$ & $426 / 386$ & $208 / 188$ & $0 / 0$ & $0 / 0$ & $0 / 0$ & $0 / 0$ & $12 / 0$ \\
\hline$s$ & Ann-1 & 5 & $0 / 0$ & $0 / 0$ & $0 / 0$ & $0 / 0$ & $16 / 0$ & $0 / 0$ & $10 / 0$ & $8 / 2$ & $0 / 0$ & $0 / 0$ & $0 / 0$ & $0 / 0$ & $2 / 0$ \\
\hline morus & Mul-MD & 29 & $0 / 0$ & $0 / 0$ & $0 / 0$ & $0 / 0$ & $6 / 0$ & $0 / 0$ & $16 / 2$ & $6 / 4$ & $0 / 0$ & $0 / 0$ & $0 / 0$ & $0 / 0$ & $0 / 0$ \\
\hline morus & MUL0034 & 30 & $0 / 0$ & $2 / 0$ & $0 / 0$ & $0 / 0$ & $10 / 0$ & $0 / 0$ & $12 / 0$ & $4 / 2$ & $0 / 0$ & $0 / 0$ & $0 / 0$ & $0 / 0$ & $2 / 0$ \\
\hline $\begin{array}{l}\text { Total } \\
\quad X f \text { reads }\end{array}$ & & & $0 / 0$ & $978 / 2$ & $64 / 0$ & $2 / 0$ & $15,834 / 52$ & $2,832 / 6$ & $594 / 396$ & $290 / 198$ & $0 / 0$ & $0 / 0$ & $0 / 0$ & $0 / 0$ & $3,122 / 12$ \\
\hline$X f$ subsp. & & & No $X$. & $p$ & $p$ & $p$ & $p$ & $p$ & $f / s$ & $f / s$ & No $X$. & No $X$. & No $X$. & No $X$. & $p$ \\
\hline MRS & & & $\ldots$ & CoDiRO & CoDiRO & CoDiRO & CoDiRO & CoDiRO & $\mathrm{CO} 33$ & $\mathrm{CO} 33$ & $\ldots$ & $\ldots$ & $\ldots$ & $\ldots$ & CoDiRO \\
\hline & & & & & & & & & & & & & & tinued o & next page) \\
\hline
\end{tabular}

a ST = sequence type; and MRS = most related strain. Subspecies: $f=$ fastidiosa $;=$ multiplex; $p=$ pauca; $s=$ sandyi; and No $X$. = no Xylella . More information on the samples is given in Table 5, where the sample number is in the second column. Italic indicates highest ignore mapping and underline marks the high ignore mapping of sample 21 and the highest number of reads mapped in sample 22. 
were counted in that part of the analysis. In addition to the results of the analysis with the reference strains representing the five subspecies, a read mapping against the $40 \mathrm{X}$. fastidiosa genomes from NCBI was conducted for all samples. This analysis made it possible to find which of the 40 genomes was the closest match with the bacteria in the infected samples. In the analysis, high stringent settings (length fraction 0.98, similarity fraction 0.98) and the map randomly and ignore options were used. For each sample the paired reads per reference strain were counted and displayed separately. One of the samples (sample 22) showed a relatively high number of reads mapped on one of the $X$. fastidiosa reference sequences after analyzing to subspecies level. For this sample, an MLST analysis was done based on seven loci (leuA, petC, malF, cysG, holC, nuoL, and $g l t T$ ). The ST was determined by analyzing gene sequences, derived from the sample itself, using the PubMLST database (https://pubmlst.org). To recover these gene sequences, we first did a de novo assembly using extracted reads from the mapping against the most related subspecies. Reference genes (imported from the PubMLST database) were mapped against the list of contigs, obtained from the de novo assembly, to locate the position of the MLST genes in the genome. After this read mapping, it was possible to extract the gene sequences from the assembly and to determine the ST.

De novo whole genome assembly of sample 22 was performed in CLC software by mapping the extracted reads of sample 22 that map on $X$. fastidiosa reference strain M12. The resulting $83 X$. fastidiosa contigs were annotated with Prokka 1.14 using default settings (Seemann 2014). The genome assembly and annotation quality and completeness were assessed using BUSCO 3 with the 148 genes in the bacterial reference set (Simão et al. 2015).

\section{Results}

Development of a triplex TaqMan assay. The identity of $X$. fastidiosa strains obtained from reference collections (subspecies fastidiosa, multiplex, and pauca) was confirmed using the Harper TaqMan assay and the Harper LAMP assay (data not shown). The analytical sensitivity of the simplex and multiplex TaqMan assays was determined using gBlocks and genomic DNA from pure cultures of $X$. fastidiosa as a template. After confirming the quality of the gBlocks by using the UTC TaqMan PCR check, dilution series of the two gBlocks and dilution series of $X$. fastidiosa DNA were analyzed with the simplex Harper TaqMan and triplex TaqMan PCR (Fig. 1). The

Table 6. (Continued from previous page)

\begin{tabular}{|c|c|c|c|c|c|c|c|c|c|c|c|c|c|}
\hline \multirow[b]{2}{*}{ Subsp. } & \multirow[b]{2}{*}{ Isolate no. } & \multirow[b]{2}{*}{ ST } & \multicolumn{11}{|c|}{ Sample no. } \\
\hline & & & 14 & 15 & 16 & 17 & 18 & 19 & 20 & 21 & 22 & 23 & 24 \\
\hline$p$ & CoDiRO & 53 & $398 / 0$ & $606 / 0$ & $54 / 0$ & $0 / 0$ & $2 / 0$ & $4 / 0$ & $14 / 0$ & $2 / 0$ & $146 / 0$ & $36 / 0$ & $12 / 0$ \\
\hline$p$ & De Donno & 53 & $394 / 4$ & $642 / 6$ & $62 / 0$ & $0 / 0$ & $0 / 0$ & $2 / 0$ & $8 / 0$ & $0 / 0$ & $152 / 0$ & $46 / 0$ & $18 / 0$ \\
\hline$p$ & OLS0479 & 53 & $318 / 0$ & $560 / 0$ & $42 / 0$ & $2 / 0$ & $4 / 0$ & $6 / 0$ & $10 / 0$ & $0 / 0$ & $116 / 0$ & $22 / 0$ & $26 / 0$ \\
\hline$p$ & OLS0478 & 53 & $346 / 0$ & $564 / 2$ & $32 / 0$ & $4 / 0$ & $2 / 0$ & $2 / 0$ & $6 / 0$ & $4 / 0$ & $162 / 0$ & $34 / 0$ & $42 / 0$ \\
\hline$p$ & COF0407 & 53 & $352 / 2$ & $576 / 4$ & $46 / 0$ & $0 / 0$ & $2 / 0$ & $0 / 0$ & $12 / 0$ & $6 / 0$ & $120 / 0$ & $34 / 0$ & $38 / 0$ \\
\hline$p$ & $\mathrm{~J} 1 \mathrm{a} 12$ & 11 & $40 / 0$ & $82 / 0$ & $0 / 0$ & $0 / 0$ & $2 / 0$ & $0 / 0$ & $2 / 0$ & $4 / 0$ & $126 / 0$ & $28 / 0$ & $22 / 0$ \\
\hline$p$ & $\mathrm{CVC} 0256$ & 11 & $50 / 0$ & $70 / 0$ & $6 / 0$ & $0 / 0$ & $0 / 0$ & $2 / 0$ & $0 / 0$ & $4 / 0$ & $158 / 0$ & $28 / 0$ & $26 / 0$ \\
\hline$p$ & CVC0251 & 11 & $46 / 0$ & $66 / 0$ & $10 / 0$ & $0 / 0$ & $2 / 0$ & $0 / 0$ & $6 / 0$ & $4 / 0$ & $156 / 0$ & $36 / 0$ & $32 / 0$ \\
\hline$p$ & 11399 & 11 & $48 / 0$ & $66 / 0$ & $12 / 0$ & $0 / 0$ & $0 / 0$ & $2 / 0$ & $2 / 0$ & $4 / 2$ & $172 / 0$ & $42 / 0$ & $20 / 0$ \\
\hline$p$ & $9 \mathrm{a} 5 \mathrm{c}$ & 13 & $30 / 0$ & $78 / 0$ & $12 / 0$ & $0 / 0$ & $0 / 0$ & $0 / 0$ & $4 / 0$ & $2 / 0$ & $146 / 0$ & $32 / 0$ & $34 / 0$ \\
\hline$p$ & U24D & 13 & $62 / 0$ & $68 / 0$ & $8 / 0$ & $2 / 0$ & $0 / 0$ & $0 / 0$ & $4 / 0$ & $2 / 0$ & $184 / 0$ & $44 / 0$ & $24 / 0$ \\
\hline$p$ & $6 c$ & 14 & $48 / 0$ & $80 / 0$ & $2 / 0$ & $2 / 0$ & $0 / 0$ & $0 / 0$ & $10 / 0$ & $4 / 0$ & $136 / 0$ & $34 / 0$ & $18 / 0$ \\
\hline$p$ & $\operatorname{Pr} 8 x$ & 14 & $46 / 0$ & $82 / 0$ & $6 / 0$ & $0 / 0$ & $0 / 0$ & $0 / 0$ & $4 / 0$ & $2 / 0$ & $190 / 0$ & $24 / 0$ & $20 / 0$ \\
\hline$p$ & COF0324 & 14 & $52 / 0$ & $104 / 0$ & $6 / 0$ & $0 / 0$ & $0 / 0$ & $0 / 0$ & $8 / 0$ & $4 / 0$ & $146 / 0$ & $28 / 0$ & $20 / 0$ \\
\hline$p$ & 3124 & 16 & $42 / 0$ & $46 / 0$ & $6 / 0$ & $0 / 0$ & $0 / 0$ & $2 / 0$ & $2 / 0$ & $2 / 2$ & $158 / 0$ & $44 / 0$ & $22 / 0$ \\
\hline$p$ & 32 & 16 & $56 / 0$ & $78 / 0$ & $6 / 0$ & $0 / 0$ & $0 / 0$ & $0 / 0$ & $0 / 0$ & $6 / 0$ & $126 / 0$ & $18 / 0$ & $32 / 0$ \\
\hline$p$ & $\mathrm{Fb} 7$ & 69 & $46 / 0$ & $32 / 0$ & $8 / 0$ & $0 / 0$ & $2 / 0$ & $0 / 0$ & $4 / 0$ & $4 / 0$ & $148 / 0$ & $44 / 0$ & $26 / 0$ \\
\hline$p$ & Hib4 & 70 & $58 / 2$ & $94 / 0$ & $0 / 0$ & $2 / 0$ & $0 / 0$ & $0 / 0$ & $8 / 2$ & $6 / 78$ & $182 / 2$ & $34 / 0$ & $42 / 0$ \\
\hline$p$ & CFBP8072 & 74 & $106 / 0$ & $230 / 2$ & $16 / 0$ & $4 / 0$ & $2 / 0$ & $2 / 0$ & $10 / 4$ & $8 / 2$ & $286 / 0$ & $54 / 2$ & $40 / 0$ \\
\hline$m$ & Dixon & 6 & $0 / 0$ & $0 / 0$ & $0 / 0$ & $66 / 2$ & $350 / 48$ & $236 / 10$ & $0 / 0$ & $810 / 22$ & $4,605 / 1,560$ & $9,346 / 352$ & $5,570 / 146$ \\
\hline$m$ & CFBP8418 & 6 & $2 / 0$ & $4 / 0$ & $0 / 0$ & $4 / 0$ & $306 / 0$ & $244 / 0$ & $0 / 0$ & $712 / 2$ & $4,034 / 22$ & $7,936 / 14$ & $4,894 / 18$ \\
\hline$m$ & CFBP8417 & 6 & $0 / 0$ & $4 / 0$ & $0 / 0$ & $2 / 0$ & $292 / 2$ & $186 / 0$ & $2 / 0$ & $728 / 0$ & $4,035 / 26$ & $7,640 / 8$ & $4,952 / 4$ \\
\hline$m$ & CFBP8416 & 7 & $4 / 0$ & $0 / 0$ & $0 / 0$ & $8 / 0$ & $228 / 6$ & $306 / 92$ & $0 / 0$ & $796 / 50$ & $73,432 / 25,268$ & $13,712 / 4,892$ & $8,276 / 2,516$ \\
\hline$m$ & M12 & 7 & $0 / 0$ & $0 / 0$ & $0 / 0$ & $10 / 0$ & $244 / 4$ & $232 / 0$ & $0 / 0$ & $712 / 16$ & $44,738 / 564$ & $8,516 / 112$ & $5,512 / 64$ \\
\hline$m$ & Griffin-1 & 7 & $2 / 0$ & $0 / 0$ & $0 / 0$ & $8 / 0$ & $226 / 0$ & $206 / 0$ & $2 / 0$ & $656 / 2$ & $40,526 / 42$ & $7,490 / 8$ & $4,888 / 6$ \\
\hline$m$ & $\begin{array}{l}\text { Sycamore } \\
\text { Sy-VA }\end{array}$ & 8 & $2 / 0$ & $2 / 0$ & $0 / 0$ & $16 / 0$ & $166 / 8$ & $140 / 0$ & $2 / 2$ & $518 / 10$ & $26,836 / 276$ & $4,996 / 54$ & $3,338 / 34$ \\
\hline$m$ & ATCC35871 & 41 & $2 / 0$ & $2 / 0$ & $0 / 0$ & $22 / 0$ & $148 / 4$ & $146 / 0$ & $2 / 0$ & $506 / 12$ & $27,812 / 92$ & $5,152 / 30$ & $3,418 / 20$ \\
\hline$m$ & BB01 & 42 & $8 / 0$ & $0 / 0$ & $0 / 0$ & $32 / 0$ & $168 / 4$ & $92 / 0$ & $0 / 0$ & $408 / 32$ & $21,888 / 70$ & $4,154 / 8$ & $2,770 / 6$ \\
\hline$f$ & EB92.1 & 1 & $2 / 0$ & $6 / 0$ & $2 / 0$ & $342 / 2$ & $2 / 0$ & $8 / 0$ & $0 / 0$ & $\underline{138 / 128}$ & $620 / 0$ & $146 / 0$ & $94 / 0$ \\
\hline$f$ & M23 & 1 & $0 / 0$ & $6 / 0$ & $0 / 0$ & $600 / 50$ & $6 / 2$ & $4 / 0$ & $2 / 0$ & $22 / 0$ & $1,054 / 2$ & $220 / 2$ & $166 / 0$ \\
\hline$f$ & GB514 & 1 & $0 / 0$ & $0 / 0$ & $0 / 0$ & $412 / 2$ & $4 / 0$ & $4 / 0$ & $0 / 0$ & $28 / 0$ & $904 / 0$ & $174 / 0$ & $130 / 0$ \\
\hline$f$ & Stag's Leap & 1 & $2 / 0$ & $0 / 0$ & $0 / 0$ & $444 / 0$ & $8 / 0$ & $4 / 0$ & $0 / 0$ & $30 / 2$ & $1,142 / 10$ & $212 / 4$ & $184 / 2$ \\
\hline$f$ & Temecula1 & 1 & $0 / 0$ & $4 / 0$ & $0 / 0$ & $452 / 0$ & $14 / 0$ & $6 / 0$ & $2 / 0$ & $26 / 0$ & $1,024 / 4$ & $196 / 2$ & $174 / 0$ \\
\hline$f$ & DSM 10026 & 2 & $2 / 0$ & $2 / 0$ & $0 / 0$ & $342 / 0$ & $4 / 0$ & $6 / 0$ & $4 / 0$ & $12 / 0$ & $988 / 4$ & $264 / 4$ & $154 / 0$ \\
\hline$f$ & ATCC35879 & 2 & $0 / 0$ & $2 / 0$ & $0 / 0$ & $342 / 0$ & $20 / 0$ & $8 / 0$ & $0 / 0$ & $18 / 2$ & $924 / 6$ & $194 / 0$ & $120 / 0$ \\
\hline$f$ & CFBP8073 & 75 & $0 / 0$ & $4 / 0$ & $0 / 0$ & $104 / 0$ & $12 / 0$ & $2 / 0$ & $2 / 2$ & $22 / 4$ & $604 / 0$ & $134 / 0$ & $84 / 0$ \\
\hline$f / s$ & $\mathrm{CO} 33$ & 72 & $2 / 0$ & $12 / 0$ & $0 / 0$ & $38 / 0$ & $4 / 0$ & $12 / 0$ & $6 / 2$ & $16 / 2$ & $972 / 4$ & $194 / 0$ & $150 / 0$ \\
\hline$s$ & Ann-1 & 5 & $0 / 0$ & $2 / 0$ & $0 / 0$ & $34 / 0$ & $12 / 2$ & $4 / 0$ & $2 / 2$ & $28 / 2$ & $1,100 / 58$ & $272 / 20$ & $176 / 14$ \\
\hline morus & Mul-MD & 29 & $4 / 0$ & $6 / 0$ & $2 / 0$ & $82 / 0$ & $28 / 2$ & $24 / 0$ & $0 / 0$ & $116 / 8$ & $5,148 / 12$ & $1,056 / 2$ & $734 / 2$ \\
\hline morus & MUL0034 & 30 & $4 / 0$ & $2 / 0$ & $0 / 0$ & $56 / 0$ & $42 / 2$ & $24 / 0$ & $2 / 0$ & $122 / 8$ & $5,282 / 36$ & $1,010 / 4$ & $692 / 6$ \\
\hline $\begin{array}{l}\text { Total } \\
\quad X f \text { reads }\end{array}$ & & & $2,574 / 8$ & $4,182 / 14$ & $338 / 0$ & $3,432 / 56$ & $2,302 / 84$ & $1,916 / 102$ & $142 / 14$ & $6,492 / 386$ & $384,750 / 28,058$ & $73,676 / 5,518$ & $46,990 / 2,838$ \\
\hline$X f$ subsp. & & & $p$ & $p$ & $p$ & $f$ & $m$ & $m$ & $p$ & $m$ & $m$ & $m$ & $m$ \\
\hline MRS & & & CoDiRO & De Donno & De Donno & M23 & Dixon & CFBP8416 & CFBP8072 & CFBP8416 & CFBP8416 & CFBP8416 & CFBP8416 \\
\hline
\end{tabular}


dilution series was made in a background of internal control gBlock or Acat DNA at a fixed concentration to mimic future assay conditions. Results showed a detection limit of 10 copies for the Xylella gBlock and $10 \mathrm{fg} / \mu \mathrm{l}$ using $X$. fastidiosa DNA, irrespective of whether using the Harper or Ouyang TaqMan PCR assay or whether a simplex or a triplex was performed. The triplex TaqMan assay was thereafter compared with duplex TaqMan assays (i.e., a duplex Harper/Acat and a duplex Ouyang/Acat using DNA from symptomatically infected tobacco plants). Use of the triplex TaqMan or the duplex TaqMan assays resulted in highly similar Ct values for the infected samples (Table 4).

Evaluation of metagenomics for detection and characterization of $X$. fastidios $\boldsymbol{a}$ in plant material. NGS analysis was performed on 24 DNA extracts obtained from various sources of Xylellainfected or Xylella-free plant material, which were provided by participants from different countries in a European Xylella network (Euphresco). DNA was also extracted from tobacco plant material supplemented with 10-fold serial concentrations of $X$. fastidiosa subsp. pauca (CoDiRO strain). Metadata regarding host plants, origin of the samples, and information on strains isolated from samples are summarized in Table 5. NGS reads obtained with Illumina HiSeq sequencing were initially mapped against five genome sequences representing the subspecies and subsequently against 40 genome sequences. After NGS sequencing, a total amount of paired-end reads between 5.1 and 7.8 million (Table 5) with a mean read length of $500 \mathrm{bp}$ were produced for the 24 DNA samples extracted from the plant material. NGS data derived from the 24 DNA extracts showed that in all infected plant material but not in Xylella-free plant material, reads were found that mapped with the $X$. fastidiosa reference genomes (Table 5). In DNA extracts obtained from Xylella-free tobacco sap, supplemented with a serial dilution of $X$. fastidiosa subsp. pauca (CoDiRO strain) suspension (samples 2, 3, and 4), a decreasing number of mapped reads were found. The most diluted sample, supplemented with $10^{4}$ cells $/ \mathrm{ml}$, resulted in only two mapped reads. These reads showed a $100 \%$ match with the CoDiRO reference genome. Similarly, in infected tobacco and Catharanthus plant material, steminoculated with the CoDiRO strain (samples 5 and 6), a relatively high number of reads mapped on the CoDiRO genome sequence. Metagenomic analysis showed that the reads of the infected samples from Italy (samples 13 to 16) mapped clearly on the CoDiRO strain genome sequence. Read mapping of the infected samples from Spain (samples 17 to 21) resulted in a tentative classification of the pathogen in three different subspecies (multiplex, fastidiosa, and pauca). Reads in the three infected samples from France (samples 22 to 24) mapped on the multiplex reference genome. DNA sample 22 from France, which was extracted from infected Spartium junceum, gave the most mapped reads $(301,838)$ on the multiplex reference genome. In addition, metagenomic analysis was conducted on intercepted Coffea plants, one sample from Austria (sample 7) and one from the Netherlands (sample 8 ). The number of reads that mapped with the $X$. fastidiosa reference genomes was relatively low but indicated infections with $X$. fastidiosa subsp. fastidiosa, although reads also mapped on reference genomes of other subspecies even using the ignore option. In all samples where $X$. fastidiosa was detected, a tentative identification on subspecies level was given (Table 5). The results of the first metagenomic analysis were confirmed by using all the available 40 reference genomes from the NCBI database instead of five reference genomes for the subspecies (Table 6). The reads derived from samples containing the CoDiRO strain (samples 2 to 6 and 13 to 16) were preferentially mapped on the several ST53 X. fastidiosa subsp. pauca reference genomes. Samples 7 and 8, intercepted from Coffea plants imported from central America, were most related to the reference genome of $\mathrm{CO} 33$. This isolate (CO33) is genetically related to isolates belonging to different subspecies of $X$. fastidiosa (subsp. sandyi and subsp. morus) (Giampetruzzi et al. 2015b). Sample 17 (Spain) mapped preferentially (600 reads) on the reference genome of isolate M23, which was typed as ST1 (subsp. fastidiosa). A lower number (342 to 452 reads) mapped on other ST1 reference genomes (EB92.1, GB514, and Temecula1), indicating genetic variation within the group of ST1 isolates. Different samples from Spain and France preferentially mapped on subsp. multiplex $(18,19$, and 21 to 24$)$, showing variation in the mapping with the nine multiplex reference genomes, which is an indication of the presence of genetically different strains of this subspecies in Europe. Sample 20 (Spain) mapped with low numbers of reads on different pauca reference genomes, but also with genomes of other subspecies, complicating the identification. The tentative identification to subspecies level was given, as well as the most related strain on the basis of a random mapping. Using the ignore option (Table 6), only unique reads that map on the reference genomes are visible. Samples containing the CoDiRO strain lose their mapping reads because multiple highly similar reference genomes of that strain are included in the set of genomes. Samples from Spain show clear mapping on the most related reference genome. Only sample 21 is different. It shows with random mapping subspecies multiplex as the most related and with ignore mapping subspecies fastidiosa, although reads were also mapped on multiplex reference genomes. Colleagues from Spain analyzed this sample as ST6, whereas our read mapping showed high mapping on reference genomes of ST7 but also on ST6 reference genomes. Moreover, in the ignore option, mapping was highest on the reference genome of a subsp. fastidiosa isolate (EB92.1). Samples from France map with the ignore function preferentially on ST7 multiplex reference genome of isolate CFBP8416. Sequences of sample 22 (France) with the highest number of mapped reads were further analyzed, using the MLST approach. A de novo assembly with the 301,838 mapped reads (Table 5) resulted in the extraction of the seven full-length loci (leuA, petC, malF, cys G, holC, nuoL, and gltT) used for MLST typing. The coverage of the seven loci was between 13 and 27. It was shown that sample 22 was ST7. Interestingly, strains CFBP8417 and CFBP8418, isolated from the same host plant (S. junceum) as sample 22 in our study, belonged to ST6. The difference between ST6 and ST7 is based on a single nucleotide polymorphism (SNP) in the $c y s G$ gene (Fig. 2). A de novo assembly of the $301,838 X$. fastidiosa reads of this sample resulted in a full $X$. fastidiosa genome sequence of $2.33 \mathrm{Mb}$ consisting of 83 contigs. This draft genome was compared with the full genome sequence of isolate CFBP8416 and resulted in 81 SNPs. Gene annotation of this draft genome gave a BUSCO score of $97.3 \%$.

Finally, the triplex TaqMan PCR, the simplex Harper assay, the Harper LAMP, and the NGS results of the 24 DNA extracts from various sources of infected or Xylella-free plant material were compared (Table 7). In samples from Xylella-free plants (samples 1 and 9 to 12), no Xylella was detected in any of the assays, or a high Ct value was found exceeding 35 and with a nonexponential amplification curve. Analysis of the dilution series of CoDiRO in tobacco sap shows the expected dose response curve. The detection level for all assays was $10^{5}$ cells $/ \mathrm{ml}$. The two intercepted Coffea plants (samples 7 and 8 ) showed Ct values between 29 and 37 and a high time of positivity or no LAMP signal. The number of target reads in the NGS analysis was 368 and 242, respectively. Other samples from naturally infected plants from Italy, France, and Spain were all positive in the TaqMan assays and showed $\mathrm{Ct}$ values between 21 and 30 . The Ct values obtained with the Harper primers and probe in the triplex TaqMan assay were comparable with those in the simplex Harper TaqMan assay. LAMP reactions were positive for most of the samples, but LAMP was less sensitive compared with the TaqMan assays. NGS results strongly confirmed the TaqMan PCR and LAMP results.

\section{Discussion}

In this study, a triplex TaqMan assay for detection of $X$. fastidiosa was developed by combining two previously described TaqMan assays specific for the pathogen (Harper et al. 2010; Ouyang et al. 2013) and an assay as (internal) control for DNA extraction and amplification to improve the diagnostic specificity of the triplex assay. An assay targeting two specific loci of the pathogen will be less prone to false positive or negative reactions (Janse et al. 2010). The loci are separated approximately $900 \mathrm{kB}$ from each other on the $X$. fastidiosa genome, which will lead them to be present on different DNA fragments isolated from plants. Moreover, inclusion of an internal control, based on the supplementation of preestablished numbers of Acat cells to each sample, a bacterium taxonomically related to $X$. fastidiosa, will recognize false-negative reaction as a result of a 
failing DNA extraction or an inhibition of the amplification reaction. In all plant extracts analyzed we did not find inhibition of the PCR reaction, because all internal control amplification showed similar $\mathrm{Ct}$ values.

In multiple independent experiments, using different samples, it was shown that the triplex TaqMan PCR was as sensitive as the simplex Harper TaqMan PCR commonly used for the detection of this quarantine bacterium (Modesti et al. 2017; Olmo et al. 2017). First, the detection levels for the $X$. fastidiosa assays in a triplex and simplex format were determined at a level of 10 copies of target DNA when using designed gBlocks covering the amplicon sequences of the three assays. The gBlocks make it possibile to accurately determine the analytical sensitivity of individual assays in a multiplex setting, because the copy number of the targets, which are present in an equimolar ratio, is known. Second, the sensitivity of the triplex assay was compared with a duplex assay based on a combination of the

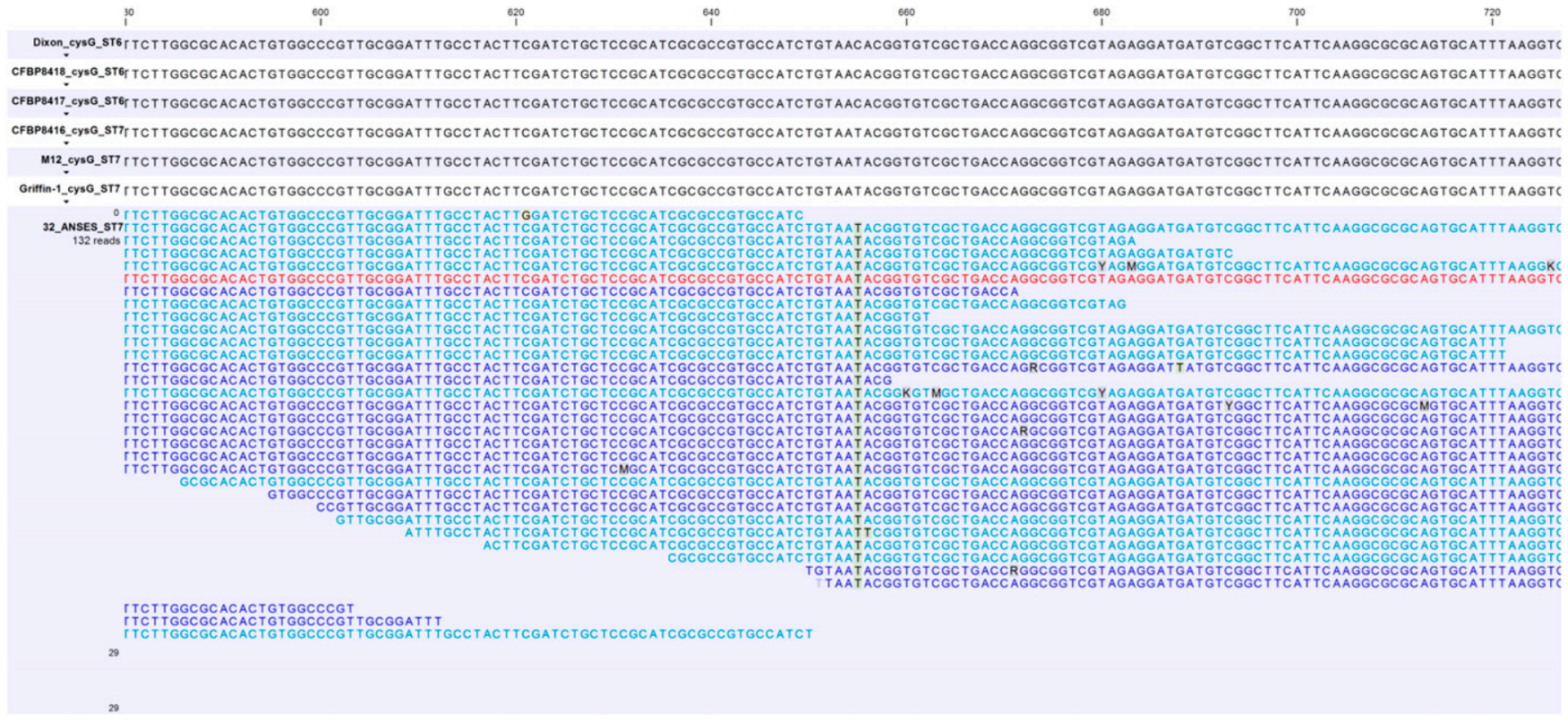

Fig. 2. Alignment of cysG sequences of ST6 and ST7 X. fastidiosa (Xf) reference isolates derived from the NCBI database and mapping of $X f$ reads of sample 22 against locus cysG. Single nucleotide polymorphism position between ST6 and ST7 (C/T) is indicated.

Table 7. Comparison of triplex TaqMan polymerase chain reaction (PCR), simplex Harper TaqMan PCR, and Harper loop-mediated isothermal amplification (LAMP) results in duplicate with next-generation sequencing (NGS) results ${ }^{\mathrm{a}}$

\begin{tabular}{|c|c|c|c|c|c|c|c|c|c|c|c|c|}
\hline \multirow{2}{*}{\multicolumn{2}{|c|}{ Plant samples }} & \multicolumn{8}{|c|}{ TaqMan PCR Ct values } & \multirow{2}{*}{\multicolumn{2}{|c|}{$\begin{array}{c}\text { LAMP } \\
\text { Time of } \\
\text { positivity } \\
\text { (min) }\end{array}$}} & \multirow{3}{*}{$\frac{\text { NGS results }}{\frac{\text { Total } X f \text { mapped reads }}{(\text { random mode })}}$} \\
\hline & & \multicolumn{2}{|c|}{$\begin{array}{l}\text { Triplex } \\
\text { Harper }\end{array}$} & \multicolumn{2}{|c|}{$\begin{array}{c}\text { Triplex } \\
\text { Ouyang } \\
\end{array}$} & \multicolumn{2}{|c|}{ Triplex Acat } & \multicolumn{2}{|c|}{$\begin{array}{l}\text { Simplex } \\
\text { Harper }\end{array}$} & & & \\
\hline No. & Information on host/ID number & 1 & 2 & 1 & 2 & 1 & 2 & 1 & 2 & 1 & 2 & \\
\hline 1 & Clean tobacco sap & I & I & I & I & 27.19 & 26.70 & I & I & I & I & I \\
\hline 2 & $10^{6} / \mathrm{ml} \mathrm{CoDiRO} \mathrm{in} \mathrm{tobacco} \mathrm{sap}$ & 32.12 & 32.37 & 31.54 & 31.59 & 27.58 & 27.24 & 32.11 & 32.14 & 39:00 & $21: 45$ & 974 \\
\hline 3 & $10^{5} / \mathrm{ml} \mathrm{CoDiRO} \mathrm{in} \mathrm{tobacco} \mathrm{sap}$ & 35.51 & 36.87 & 33.49 & 34.64 & 26.53 & 27.68 & 34.64 & 35.32 & I & 1 & 64 \\
\hline 4 & $10^{4} / \mathrm{ml} \mathrm{CoDiRO} \mathrm{in} \mathrm{tobacco} \mathrm{sap}$ & I & I & 35.82 & 38.40 & 27.63 & 27.52 & l & I & / & / & 2 \\
\hline 5 & CoDiRO inf. tobacco 12 & 24.45 & 24.38 & 23.73 & 23.61 & 26.11 & 26.41 & 24.64 & 24.48 & $15: 30$ & $15: 30$ & 15,828 \\
\hline 6 & CoDiRO inf. Catharanthus 34 & 30.56 & 31.14 & 29.47 & 29.31 & 27.24 & 26.40 & 30.45 & 30.87 & $23: 30$ & $27: 30$ & 2,826 \\
\hline 7 & AGES471/15; intercepted Coffea & 29.98 & 30.70 & 28.81 & 29.18 & 27.21 & 26.59 & 30.20 & 30.19 & $30: 15$ & $32: 15$ & 368 \\
\hline 8 & No. 1; intercepted Coffea & 35.14 & I & 32.42 & 37.05 & 27.43 & 26.51 & 34.20 & 33.80 & / & l & 242 \\
\hline 9 & Polygala myrtifolia & I & I & I & I & 27.00 & 27.68 & I & I & I & I & / \\
\hline 10 & Lavandula stoechas & l & / & 38.69 & l & 27.38 & 27.44 & l & I & / & / & l \\
\hline 11 & Nerium oleander & I & / & I & l & 26.74 & 25.97 & l & 38.18 & / & / & l \\
\hline 12 & Olea europaea & I & / & l & l & 27.15 & 27.30 & l & I & I & / & l \\
\hline 13 & APL 3XM; inf. Polygala myrtifolia & 25.95 & 25.80 & 25.45 & 25.42 & 26.78 & 25.05 & 25.88 & 25.88 & $26: 45$ & $27: 30$ & 3,120 \\
\hline 14 & APL9M; inf. Lavandula stoechas & 24.34 & 24.37 & 23.68 & 23.85 & 26.23 & 25.53 & 24.40 & 24.42 & $20: 00$ & $20: 45$ & 2,568 \\
\hline 15 & APL4XM; inf. Olea europaea & 24.32 & 24.38 & 23.92 & 23.81 & 26.22 & 25.88 & 24.31 & 24.32 & $23: 15$ & $25: 30$ & 4,158 \\
\hline 16 & APL OL2-bis; inf. Nerium oleander & 28.98 & 30.00 & 28.09 & 27.62 & 27.50 & 27.05 & 29.01 & 29.10 & $27: 30$ & I & 396 \\
\hline 17 & 5387; inf. Prunus dulcis & 30.22 & 30.40 & 29.02 & 28.89 & 27.16 & 27.15 & 30.45 & 30.12 & $37: 00$ & l & 3,356 \\
\hline 18 & 5626; inf. Olea europaea europaea & 27.92 & 27.96 & 27.35 & 27.30 & 27.34 & 27.26 & 27.85 & 28.09 & $32: 45$ & $35: 15$ & 2,092 \\
\hline 19 & $5382 ;$ inf. Polygala myrtifolia & 28.45 & 28.49 & 27.77 & 27.98 & 27.23 & 27.29 & 28.49 & 28.48 & $27: 15$ & / & 1,824 \\
\hline 20 & 5402; inf. Olea europaea europaea & 28.79 & 28.62 & 28.07 & 27.89 & 27.05 & 27.02 & 29.01 & 29.16 & $27: 15$ & $37: 30$ & 130 \\
\hline 21 & EM_1; inf. Prunus dulcis & 26.43 & 26.43 & 25.85 & 25.80 & 26.75 & 27.01 & 26.68 & 26.69 & $24: 15$ & $26: 45$ & 6,172 \\
\hline 22 & 326.1(A); inf. Spartium junceum & 22.16 & 22.16 & 21.35 & 21.36 & 26.34 & 25.29 & 22.16 & 22.14 & $20: 30$ & $21: 15$ & 351,534 \\
\hline 23 & 327.2 (A); inf. Coronilla glauca & 22.15 & 22.13 & 21.39 & 21.38 & 25.14 & 26.07 & 22.11 & 21.78 & $20: 30$ & $20: 45$ & 66,652 \\
\hline 24 & 328.2 (A); inf. Polygala myrtifolia & 23.40 & 23.43 & 22.77 & 22.76 & 24.31 & 26.40 & 23.40 & 23.43 & 23:00 & $21: 45$ & 43,038 \\
\hline
\end{tabular}

${ }^{\text {a }} X f=X$. fastidiosa $; /=X f$ negative; italic $=$ positive $X f$ score in TaqMan PCR, LAMP, and NGS; bold $=$ suspicious score with high Ct value; and Acat $=$ Acidovorax cattleyae. Sources of samples and more information in Table 5. 
Harper TaqMan and the TaqMan for the internal control, using symptomatic tobacco plant material that had been infected artificially with the CoDiRO strain. In this comparison, the $\mathrm{Ct}$ values of the Harper TaqMan assay in the duplex and triplex format were largely similar. Third, the sensitivity of the triplex assay with a Harper simplex assay was compared using 24 DNA extracts from spiked, artificially inoculated, and naturally infected or X. fastidiosa-free plant extracts from different origins within Europe. Also, in this experiment, the Ct values of the triplex and simplex assays were largely similar, indicating the same sensitivity. The specificity of the triplex assay is substantially improved owing to targeting two loci that are clearly separated on the $X$. fastidiosa genome instead of only one locus.

We also demonstrated the potential of NGS coupled with a metagenomic analysis for diagnostic research of $X$. fastidiosa-infected host plants. Although we did not repeat the NGS procedure on multiple DNA extractions of the same plant, the results obtained were clear for the analyzed samples. Multiple extractions may lead to different amounts of $X$. fastidiosa, because the bacterium might not be distributed equally in the plant. It is important to detect $X$. fastidiosa on subspecies level, because different subspecies have different host ranges (EFSA 2016). At the moment, subspecies are determined by amplicon sequencing of seven housekeeping genes (i.e., leuA, petC, malF, cysG, holC, nuoL, and gltT) using Sanger sequencing technology (Yuan et al. 2010). When one of the PCRs to amplify the seven loci fails, sequence typing is impossible. To circumvent tedious amplicon sequencing, we explored the possibilities of a metagenomic approach. Comparative studies using $X$. fastidiosa-infected and $X$. fastidiosa-free plant extracts indicated that the diagnostic sensitivity of metagenomics was largely similar to that of the TaqMan assays. The metagenomics study, however, provided additional information. The use of 40 reference genome sequences present in GenBank representing the five subspecies enabled us to identify $X$. fastidiosa in most of the infected plants up to the subspecies level. In the CLC software we used first the map randomly option, which means that if a read can be equally mapped to the reference genome of more than one subspecies, it randomly selects one of those subspecies. The identification of the pathogen in some samples was ambiguous. Samples 7 and 8, for example, which came from intercepted Coffea plants from central America, both mapped almost completely on the reference genome sequence of isolate $\mathrm{CO} 33$, which was classified as a hybrid of the subspecies fastidiosa and sandyi. Samples from Spain and France, which mapped on subspecies pauca, fastidiosa, and multiplex reference genomes, showed different amounts of mapped reads, indicating polymorphism between the subspecies samples. When using the ignore settings, the equally mapped reads were ignored. In analyzing the samples from different countries and from $X$. fastidiosa-infected and $X$. fastidiosa-free plant material using the set of five and 40 reference genomes of Xylella available, either in the random or ignore mapping mode, we showed clearly that Xylella-free plants showed no mapped reads at all. Samples containing the CoDiRO strain mapped exclusively on ST53 reference genomes. In the ignore setting, all reads were lost owing to multiple ST53 reference genomes included in the set of 40 genomes. In several samples we found sequence variation within an ST: for example, differences between $X$. fastidiosa subsp. multiplex ST6 and ST7 mapping for samples 18,19 , and 21 to 24 and the $X$. fastidiosa subsp. fastidiosa ST1 mapping for sample 17. If samples were infected with multiple isolates or even multiple subspecies, we need to perform more research and analysis of the data.

Using the metagenomic approach, only in highly infected material with a high genome coverage the ST of $X$. fastidiosa could be determined. In our study, this was only possible for a $S$. junceum sample (no. 22) from France, which yielded the highest number of mapped reads $(301,838)$, which was classified as ST7 using the MLST approach. Interestingly, isolates that were also obtained from another S. junceum plant (CFBP8417 and CFBP8418) were not classified as ST7 but as ST6. Obviously, this plant species can be infected with different STs. The difference was proven by analysis of the $c y s G$ locus of sample 22. A de novo assembly of the 301,838 X. fastidiosa reads of this sample resulted in a full $X$. fastidiosa genome sequence of $2.33 \mathrm{Mb}$ consisting of 83 contigs, which is comparable to other genome sequences of $X$. fastidiosa (Table 3). This draft genome was compared with the full genome sequence of isolate CFBP8416 and resulted in 81 SNPs, which can be used for track and trace studies. Gene annotation of this draft genome gave a BUSCO score of $97.3 \%$, showing the power of this NGS approach. For other samples, the number of $X$. fastidiosa reads was too low. Because we pooled 24 samples into one lane of the Illumina HiSeq, there are possibilities for other samples if we would sequence them again and use only one sample per lane.

In this huge NGS experiment we did not include replicates because individual extracts were sent to us for NGS analysis, triplex TaqMan PCR, and LAMP. Therefore, not enough DNA was available to reproduce the NGS results. However, multiple extracts of different hosts of the CoDiRO strain were analyzed and proved the presence of $X$. fastidiosa ST53 in those samples. After comparing the results of the TaqMan assays with the NGS results, we can conclude that there is a great similarity in the results. LAMP was slightly less sensitive compared with TaqMan assays. In our studies a novel, unbiased metagenomics approach was used to detect plant pathogenic bacteria in plant material, which requires no a priori knowledge of the host or pathogen. The technique is shown to be suitable for rapid confirmation of results of TaqMan assays and to identify strains to the subspecies level, although high concentrations of the pathogen should be present in the sample. We also showed that in-depth analysis of the mapped reads resulted in detection of SNPs, which can be used for track-and-trace studies.

\section{Acknowledgments}

DNA samples from $X$. fastidiosa-infected plants were kindly provided by Maria Saponari (IPSP, Italy), Francoise Poliakoff (ANSES, France), Blanca Landa (CSIC, Spain), Richard Gottsberger (AGES, Austria), and Maria Vlami (NVWA, Netherlands). The internal control Acat, primers, probe, and sequences were kindly provided by Naktuinbouw (Netherlands). The UTC was developed by Marga van Gent-Pelzer (WUR).

\section{Literature Cited}

Almeida, R. P. P., and Nunney, L. 2015. How do plant diseases caused by Xylella fastidiosa emerge? Plant Dis. 99:1457-1467.

EFSA. 2016. Scientific report on the update of a database of host plants of Xylella fastidiosa: 20 November 2015. EFSA J. 14:4378.

EPPO. 2015. Xylella fastidiosa detected in Alpes-Maritimes, mainland France. EPPO Reporting Service, no. 10, 2015/180.

EPPO. 2016a. EPPO Standards. Phytosanitary procedures-PM 3/81 (1) Inspection of consignments for Xylella fastidiosa. EPPO Bull. 46:385-406.

EPPO. 2016b. First report of Xylella fastidiosa in Spain. EPPO Reporting Service, no. $11,2016 / 213$.

EPPO. 2017. Xylella fastidiosa detected in mainland Spain and update for Baleares. EPPO Reporting Service no. 7, 2017/133.

Firrao, G., and Bazzi, C. 1994. Specific identification of Xylella fastidiosa using the polymerase chain reaction. Phytopathol. Mediterr. 33:90-92.

Francis, M., Lin, H., Cabrera-La Rosa, J., Doddapaneni, H., and Civerolo, E. L. 2006. Genome-based PCR primers for specific and sensitive detection and quantification of Xylella fastidiosa. Eur. J. Plant Pathol. 115:203-213.

Giampetruzzi, A., Chiumenti, M., Saponari, M., Donvito, G., Italiano, A., Loconsole, G., Boscia, D., Cariddi, C., Martelli, G. P., and Saldarelli, P. 2015a. Draft genome sequence of the Xylella fastidiosa CoDiRO strain. Genome Announc. 3:e01538-e14.

Giampetruzzi, A., Loconsole, G., Boscia, D., Calzolari, A., Chiumenti, M. Martelli, G. P., Saldarelli, P., Almeida, R. P., and Saponari, M. 2015b. Draft genome sequence of CO33, a coffee-infecting isolate of Xylella fastidiosa. Genome Announc. 3:e01472-e15.

Giampetruzzi, A., Saponari, M., Almeida, R. P. P., Essakhi, S., Boscia, D., Loconsole, G., and Saldarelli, P. 2017a. Complete genome sequence of the olive-infecting strain Xylella fastidiosa subsp. pauca De Donno. Genome Announc. 5:e00569-e17.

Giampetruzzi, A., Saponari, M., Loconsole, G., Boscia, D., Savino, V. N., Almeida, R. P. P., Zicca, S., Landa, B. B., Chacón-Diaz, C., and Saldarelli, P. 2017b. Genome-wide analysis provides evidence on the genetic relatedness of the emergent Xylella fastidiosa genotype in Italy to isolates from Central America. Phytopathology 107:816-827.

Harper, S. J., Ward, L. I., and Clover, G. R. G. 2010. (Erratum 2013). Development of LAMP and real-time PCR methods for the rapid detection of Xylella fastidiosa for quarantine and field applications. Phytopathology 100:1282-1288.

Ito, T., and Suzaki, K. 2017. Universal detection of phytoplasmas and Xylella spp. by TaqMan singleplex and multiplex real-time PCR with dual priming oligonucleotides. PLoS One 12:e0185427. 
Janse, I., Hamidjaja, R. A., Bok, J. M., and van Rotterdam, B. J. 2010. Reliable detection of Bacillus anthracis, Francisella tularensis and Yersinia pestis by using multiplex qPCR including internal controls for nucleic acid extraction and amplification. BMC Microbiol. 10:314.

Kuske, C. R., Barns, S. M., Grow, C. C., Merrill, L., and Dunbar, J. 2006. Environmental survey for four pathogenic bacteria and closely related species using phylogenetic and functional genes. J. Forensic Sci. 51:548-558.

Li, W., Teixeira, D. C., Hartung, J. S., Huang, Q., Duan, Y., Zhou, L., Chen, J., Lin, H., Lopes, S., Ayres, A. J., and Levy, L. 2013. Development and systematic validation of qPCR assays for rapid and reliable differentiation of Xylella fastidiosa strains causing citrus variegated chlorosis. J. Microbiol. Methods 92:79-89.

Loconsole, G., Potere, O., Boscia, D., Altamura, G., Djelouah, K., Elbeaino, T., Frasheri, D., Lorusso, D., Palmisano, F., Pollastro, P., Silletti, M. R., Trisciuzzi, N., Valentini, F., Savino, V., and Saponari, M. 2014. Detection of Xylella fastidiosa in olive trees by molecular and serological methods. J. Plant Pathol. 96:7-14.

Loconsole, G., Saponari, M., Boscia, D., D’Attoma, G., Morelli, M., Martelli, G. P., and Almeida, R. P. P. 2016. Intercepted isolates of Xylella fastidiosa in Europe reveal novel genetic diversity. Eur. J. Plant Pathol. 146:85-94.

Mendes, R., Kruijt, M., De Bruijn, I. Dekkers, E., van der Voort, M., Schneider, J. H., Piceno, Y. M., DeSantis, T. Z., Andersen, G. L., Bakker, P. A., and Raaijmakers, J. M. 2011. Deciphering the rhizosphere microbiome for disease-suppressive bacteria. Science 332:1097-1100.

Minsavage, G. V., Thompson, C. M., Hopkins, D. L., Leite, R. M. V. B. C., and Stall, R. E. 1994. Development of a polymerase chain reaction protocol for detection of Xylella fastidiosa in plant tissue. Phytopathology 84:456-461.

Modesti, V., Pucci, N., Lucchesi, S., Campus, L., and Loreti, S. 2017. Experience of the Latium region (Central Italy) as a pest-free area for monitoring of Xylella fastidiosa: Distinctive features of molecular diagnostic methods. Eur. J. Plant Pathol. 148:557-566.

Nunney, L., Hopkins, D. L., Morano, L. D., Russell, S. E., and Stouthamer, R. 2014a. Intersubspecific recombination in Xylella fastidiosa strains native to the United States: Infection of novel hosts associated with an unsuccessful invasion. Appl. Environ. Microbiol. 80:1159-1169.

Nunney, L., Ortiz, B., Russell, S. A., Sánchez, R. R., and Stouthamer, R. 2014b. The complex biogeography of the plant pathogen Xylella fastidiosa: Genetic evidence of introductions and subspecific introgression in Central America. PLoS One 9:e112463.

Nunney, L., Schuenzel, E. L., Scally, M., Bromley, R. E., and Stouthamer, R. 2014c. Large-scale intersubspecific recombination in the plant-pathogenic bacterium Xylella fastidiosa is associated with the host shift to mulberry. Appl. Environ. Microbiol. 80:3025-3033.

Olmo, D., Nieto, A., Adrover, F., Urbano, A., Beidas, O., Juan, A., Marco-Noales, E., López, M. M., Navarro, I., Monterde, A., Montes-Borrego, M., Navas-
Cortés, J. A., and Landa, B. B. 2017. First detection of Xylella fastidiosa infecting cherry (Prunus avium) and Polygala myrtifolia plants, in Mallorca Island, Spain. Plant Dis. 101:1820.

Ouyang, P., Arif, M., Fletcher, J., Melcher, U., and Ochoa Corona, F. M. 2013. Enhanced reliability and accuracy for field deployable bioforensic detection and discrimination of Xylella fastidiosa subsp. pauca, causal agent of citrus variegated chlorosis using Razor Ex technology and TaqMan quantitative PCR. PLoS One 8:e81647.

Reisenzein, H. 2017. PCR assays for the detection of Xylella fastidiosa: Review and comparison of published protocols. Pages 57-60 in: Xylella fastidiosa \& the Olive Quick Decline Syndrome (OQDS): A serious worldwide challenge for the safeguard of olive trees. A. M. D'Onghia, S. Brunel, and F. Valentini, eds. CIHEAM, Bari, Italy.

Saponari, M., Boscia, D., Nigro, F., and Martelli, G. P. 2013. Identification of DNA sequences related to Xylella fastidiosa in oleander, almond and olive trees exhibiting leaf scorch symptoms in Apulia (Southern Italy). J. Plant Pathol. 95:668.

Schaad, N. W., Opgenorth, D., and Gaush, P. 2002. Real-time polymerase chain reaction for one-hour on-site diagnosis of Pierce's disease of grape in early season asymptomatic vines. Phytopathology 92:721-728.

Seemann T. 2014. Prokka: Rapid prokaryotic genome annotation. Bioinformatics 30:2068-2069.

Simão, F. A., Waterhouse, R. M., Ioannidis, P., Kriventseva, E. V., and Zdobnov, E. M. 2015. BUSCO: Assessing genome assembly and annotation completeness with single-copy orthologs. Bioinformatics 31:3210-3212.

Simpson, A. J. G., Reinach, F. C., Arruda, P., Abreu, F. A., Acencio, M. Alvarenga, R., Alves, L. M. C., Araya, J. E., Baia, G. S., Baptista, C. S., Barros, M. H., Bonaccorsi, E. D., Bordin, S., Bové, J. M., Briones, M. R. S., ..., and Setubal, J. C. 2000. The genome sequence of the plant pathogen Xylella fastidiosa: The Xylella fastidiosa consortium of the organization for nucleotide sequencing and analysis, Sao Paulo, Brazil. (Review) Nature 406: 151-157.

Wells, J. M., Raju, B. C., Hung, H. Y., Weisburg, W. G., Mandelco-Paul, L., and Brenner, D. J. 1987. Xylella fastidiosa gen. nov., sp. nov: Gram-negative, xylem-limited, fastidious plant bacteria related to Xanthomonas spp. Int. J. Syst. Bacteriol. 37:136-143.

Yaseen, T., Drago, S., Valentini, F., Elbeaino, T., Stampone, G., Digiaro, M., and D'Onghia, A. M. 2015. On-site detection of Xylella fastidiosa in host plants and in "spy insects" using the real-time loop-mediated isothermal amplification method. Phytopathol. Mediterr. 54:488-496.

Yuan, X., Morano, L., Bromley, R., Spring-Pearson, S., Stouthamer, R., and Nunney, L. 2010. Multilocus sequence typing of Xylella fastidiosa causing Pierce's disease and oleander leaf scorch in the United States. Phytopathology 100:601-611. 